\title{
DASH Dietary Pattern and Cardiometabolic Outcomes: An Umbrella Review of Systematic Reviews and Meta-Analyses
}

\author{
Laura Chiavaroli ${ }^{1,2} \mathbb{D}$, Effie Viguiliouk ${ }^{1,2}$, Stephanie K Nishi ${ }^{1,2}$, Sonia Blanco Mejia ${ }^{1,2} \mathbb{D}$, \\ Dario Rahelić $^{3,4}$, Hana Kahleová ${ }^{5,6}{ }^{(}$, Jordi Salas-Salvadó ${ }^{7,8} \mathbb{D}^{\text {, Cyril WC Kendall }}{ }^{1,2,9}$ and \\ John L Sievenpiper 1,2,10,11,*
}

1 Toronto 3D Knowledge Synthesis and Clinical Trials Unit, Clinical Nutrition and Risk Factor Modification Center, St. Michael's Hospital, Toronto, ON M5C 2T2, Canada; laura.chiavaroli@alumni.utoronto.ca (L.C.); effie.viguiliouk@mail.utoronto.ca (E.V.); s.nishi@mail.utoronto.ca (S.K.N.); sonia.blancomejia@mail.utoronto.ca (S.B.M.); cyril.kendall@utoronto.ca (C.WCK.)

2 Department of Nutritional Sciences, Faculty of Medicine, University of Toronto, Toronto, ON M5S 1A8, Canada

3 Department of Endocrinology, Diabetes and Clinical Pharmacology, Dubrava University Hospital, 10000 Zagreb, Croatia; dario.rahelic@gmail.com

4 School of Medicine, University of Zagreb, 10000 Zagreb, Croatia

5 Institute for Clinical and Experimental Medicine, Diabetes Centre, 14021 Prague, Czech Republic; hana.kahleova@gmail.com

6 Physicians Committee for Responsible Medicine, Washington, DC 20016-4131, USA

7 CIBER Fisiopatología de la Obesidad y Nutrición (CIBERObn), Instituto de Salud Carlos III, Madrid 28029, Spain; jordi.salas@urv.cat

8 Human Nutrition Unit, Biochemistry and Biotechnology Department, Hospital Universitari de Sant Joan de Reus, IISPV, Universitat Rovira i Virgili, Reus 43201, Spain

9 College of Pharmacy and Nutrition, University of Saskatchewan, Saskatoon, SK S7N 2Z4, Canada

10 Division of Endocrinology and Metabolism, St. Michael's Hospital, Toronto, Ontario M5C 2T2, Canada

11 Li Ka Shing Knowledge Institute, St. Michael's Hospital, Toronto, ON M5C 2T2, Canada

* Correspondence: john.sievenpiper@utoronto.ca; Tel.: 416-867-3732; Fax: 416-867-7495

Received: 15 January 2019; Accepted: 30 January 2019; Published: 5 February 2019

\begin{abstract}
Background: The Dietary Approaches to Stop Hypertension (DASH) dietary pattern, which emphasizes fruit, vegetables, fat-free/low-fat dairy, whole grains, nuts and legumes, and limits saturated fat, cholesterol, red and processed meats, sweets, added sugars, salt and sugar-sweetened beverages, is widely recommended by international diabetes and heart association guidelines. Objective: To summarize the available evidence for the update of the European Association of the Study of Diabetes (EASD) guidelines, we conducted an umbrella review of existing systematic reviews and meta-analyses using the Grading of Recommendations Assessment, Development, and Evaluation (GRADE) approach of the relation of the DASH dietary pattern with cardiovascular disease and other cardiometabolic outcomes in prospective cohort studies and its effect on blood pressure and other cardiometabolic risk factors in controlled trials in individuals with and without diabetes. Methods: MEDLINE and EMBASE were searched through 3 January 2019. We included systematic reviews and meta-analyses assessing the relation of the DASH dietary pattern with cardiometabolic disease outcomes in prospective cohort studies and the effect on cardiometabolic risk factors in randomized and non-randomized controlled trials. Two independent reviewers extracted relevant data and assessed the risk of bias of individual studies. The primary outcome was incident cardiovascular disease (CVD) in the prospective cohort studies and systolic blood pressure in the controlled trials. Secondary outcomes included incident coronary heart disease, stroke, and diabetes in prospective cohort studies and other established cardiometabolic risk factors in controlled trials. If the search did not identify an existing systematic review and meta-analysis on a pre-specified
\end{abstract}


outcome, then we conducted our own systematic review and meta-analysis. The evidence was summarized as risk ratios (RR) for disease incidence outcomes and mean differences (MDs) for risk factor outcomes with $95 \%$ confidence intervals (95\% CIs). The certainty of the evidence was assessed using GRADE. Results: We identified three systematic reviews and meta-analyses of 15 unique prospective cohort studies $(n=942,140)$ and four systematic reviews and meta-analyses of 31 unique controlled trials $(n=4,414)$ across outcomes. We conducted our own systematic review and meta-analysis of 2 controlled trials $(n=65)$ for HbA1c. The DASH dietary pattern was associated with decreased incident cardiovascular disease (RR, $0.80(0.76-0.85))$, coronary heart disease $(0.79$ $(0.71-0.88))$, stroke $(0.81(0.72-0.92))$, and diabetes $(0.82(0.74-0.92))$ in prospective cohort studies and decreased systolic (MD, $-5.2 \mathrm{mmHg}(95 \% \mathrm{CI},-7.0$ to -3.4$))$ and diastolic $(-2.60 \mathrm{mmHg}(-3.50$ to $-1.70)$ ) blood pressure, Total-C $(-0.20 \mathrm{mmol} / \mathrm{L}(-0.31$ to -0.10$))$, LDL-C $(-0.10 \mathrm{mmol} / \mathrm{L}(-0.20$ to -0.01$)), \mathrm{HbA} 1 \mathrm{c}(-0.53 \%(-0.62,-0.43))$, fasting blood insulin $(-0.15 \mu \mathrm{U} / \mathrm{mL}(-0.22$ to -0.08$))$, and body weight $(-1.42 \mathrm{~kg}(-2.03$ to -0.82$))$ in controlled trials. There was no effect on HDL-C, triglycerides, fasting blood glucose, HOMA-IR, or CRP. The certainty of the evidence was moderate for SBP and low for CVD incidence and ranged from very low to moderate for the secondary outcomes. Conclusions: Current evidence allows for the conclusion that the DASH dietary pattern is associated with decreased incidence of cardiovascular disease and improves blood pressure with evidence of other cardiometabolic advantages in people with and without diabetes. More research is needed to improve the certainty of the estimates.

Keywords: dietary approaches to stop hypertension; DASH; cardiometabolic health; cardiovascular disease; review; GRADE

\section{Introduction}

Cardiovascular disease (CVD) continues to be a leading cause of mortality in people with and without diabetes globally [1-3]. Clinical practice guidelines recommend dietary strategies as the cornerstone of therapy to prevent and manage cardiovascular disease [4-9]. The dietary approaches to stop hypertension (DASH) dietary pattern, which emphasizes fruit, vegetables, fat-free/low-fat dairy, whole grains, nuts and legumes, and limits total and saturated fat, cholesterol, red and processed meats, sweets, added sugars, and sugar-sweetened beverages, was originally developed through research sponsored by the US National Institutes of Health (NIH) to treat hypertension without medication and successfully demonstrated a clinically meaningful blood pressure lowering effect [10].

In addition to reducing blood pressure, the DASH dietary pattern has since been shown to have a decreasing effect on low-density lipoprotein-cholesterol (LDL-C) among other cardiometabolic risk factors in randomized controlled trials and be associated with reductions in diabetes and cardiovascular mortality in prospective cohort studies [11-13].

These benefits of the DASH dietary pattern have been recognized by general dietary guidelines from the U.S.-based National Heart, Lung, and Blood Institute (NHLBI) and the United States Department of Agriculture (USDA) [14]. International diabetes [7,15] and cardiovascular [6,16,17] clinical practice guidelines have also recommended the DASH dietary pattern for cardiovascular risk reduction. The European Association for the Study of Diabetes (EASD), however, has not reviewed the evidence or made specific recommendations regarding the DASH dietary pattern in its clinical practice guidelines for nutrition therapy. To update current recommendations, the Diabetes and Nutrition Study Group (DNSG) of the EASD commissioned an umbrella review of existing systematic reviews and meta-analyses using the Grading of Recommendations Assessment, Development, and Evaluation (GRADE) approach to summarize the available evidence of the relation of the DASH dietary pattern with diabetes and cardiovascular outcomes in prospective cohort studies and its effect on 
blood pressure and other established cardiometabolic risk factors in randomized and non-randomized controlled trials.

\section{Materials and Methods}

\subsection{Design}

Public health policy and clinical practice guidelines are established with the use of systematic reviews and meta-analyses of controlled trials and prospective cohort studies, which are regarded as the best levels of evidence. We thus identified the most recent systematic reviews and meta-analyses assessing the relationships of the DASH dietary pattern with incident cardiometabolic diseases in prospective cohort studies and on cardiometabolic risk factors in randomized and non-randomized controlled trials in individuals with and without diabetes. The umbrella review was conducted according to the principals of the Cochrane Handbook for Systematic Reviews of Interventions [18] and the GRADE handbook [19] with reporting according to the Preferred Reporting Items for Systematic Reviews and Meta-Analyses (PRISMA) [20]. The study protocol was registered (clinicaltrials.gov identifier, NCT03542370).

\subsection{Study selection}

The databases Medline and Embase were searched from inception through 3 January 2019 using the search terms "dietary approaches to stop hypertension" or "DASH" and "meta-analysis" (Supplemental Table S1). If the search of systematic reviews and meta-analyses did not identify an existing systematic review and meta-analysis on any of the pre-specified outcomes below, then we conducted our own systematic review and meta-analysis in which studies were eligible if the intervention was a DASH dietary pattern and the outcomes of interest were reported.

\subsection{Data extraction}

Two independent reviewers extracted relevant data from each included systematic review and meta-analysis and from invidual studies if we had to conduct our own systmatic review and meta-analysis.

\subsection{Risk of Bias Assessment}

The quality of the individual studies contained in each systematic review and meta-analysis was assessed by the two independent reviewers. Study characteristics were extracted and risk of bias assessments were performed using either the New Castle Ottawa score [21] for the prospective cohort studies or the Cochrane Risk of Bias Tool [22] for the controlled trials.

\subsection{Outomes}

The primary outcome was incident CVD in the prospective cohort studies and SBP in the controlled trials. Secondary outcomes included incident coronary heart disease (CHD), stroke, and diabetes in the prospective cohort studies and diastolic blood pressure (DBP), blood lipids (Total-cholesterol (Total-C), LDL-C, high-density lipoprotein-cholesterol (HDL-C), and triglycerides), glycemic control ( $\mathrm{HbA1c}$, fasting blood glucose, fasting blood insulin, homeostasis model assessment of insulin resistance (HOMA-IR)), adiposity (body weight), and inflammation (C-reactive protein) in the controlled trials.

\subsection{Evidence Synthesis}

All of the available evidence for each systematic review and meta-analysis identified was summarized, including pooled risk ratios for reports of prospective cohorts and pooled effect estimates of mean differences (MDs) for reports of controlled trials. Where we conducted our own 
meta-analysis, the generic inverse variance method with fixed or random effects models were used where appropriate [18].

\subsection{Grading of the Evidence}

The certainty of the evidence was assessed using the GRADE tool [19,23-34]. This tool allows evidence to be graded as high, moderate, low, or very low quality. Randomized controlled trials start as high-quality evidence and observational studies such as prospective cohort studies start as low-quality evidence. Both can then be downgraded or upgraded on the basis of pre-specified criteria. The criteria used to downgrade evidence include study limitations (weight of studies showing risk of bias as assessed by the Cochrane Risk of Bias Tool [22] or the New Castle Ottawa Scale [21], unless otherwise specified), inconsistency (substantial unexplained inter-study heterogeneity, $\mathrm{I}^{2} \geq 50 \%$ and $P<0.10$ ), indirectness (presence of factors that limit the generalizability of the results), imprecision (the $95 \%$ confidence intervals (95\% CIs) for MDs and risk estimates are wide or cross a minimally important difference), and publication bias (significant evidence of small-study effects). The criteria used to upgrade the quality of evidence are restricted to prospective cohort studies. These criteria include a large magnitude of association (relative risk, $(R R) \leq 0.5$ or $\geq 2$ ), a dose-response gradient, and attenuation by plausible confounding.

\section{Results}

\subsection{Search Results}

Figure 1 illustrates the literature search and selection process. We identified 125 reports from the search, of which 60 were excluded for title and abstract. Of 17 reports that were reviewed in full, seven reports met eligibility criteria and were included. We identified three systematic reviews and meta-analyses of 15 unique prospective cohort studies $(n=942,140)$ and four systematic reviews and meta-analyses of 31 unique controlled trials $(n=4414)$ across outcomes.

\subsection{Outcomes}

\subsubsection{Systematic Reviews and Meta-Analyses of Prospective Cohort Studies}

Cardiovascular Disease Incidence

One systematic review and meta-analysis assessed the relationship between consumption of the DASH dietary pattern and CVD incidence (including incidence and mortality of CVD, CHD, stroke and sudden cardiac death) [13] (Figure 2, Table 1, and Supplemental Table S2). It included 11 prospective cohort comparisons [35-42] ( $n=783,732 ; 32,927$ events) conducted in various countries, including the United States (seven studies), Sweden (two studies), China (one study), and Italy (one study), with follow-up durations ranging from 7.9 to 24 years [13]. The consumption of a DASH dietary pattern was found to significantly reduce CVD ( $R R=0.80$ (95\% CI: 0.76-0.85), which showed no evidence of inter-study heterogeneity $\left(\mathrm{I}^{2}=30 \%\right)$ [13]. No serious risk of bias was identified (Supplemental Tables S3-S4). 


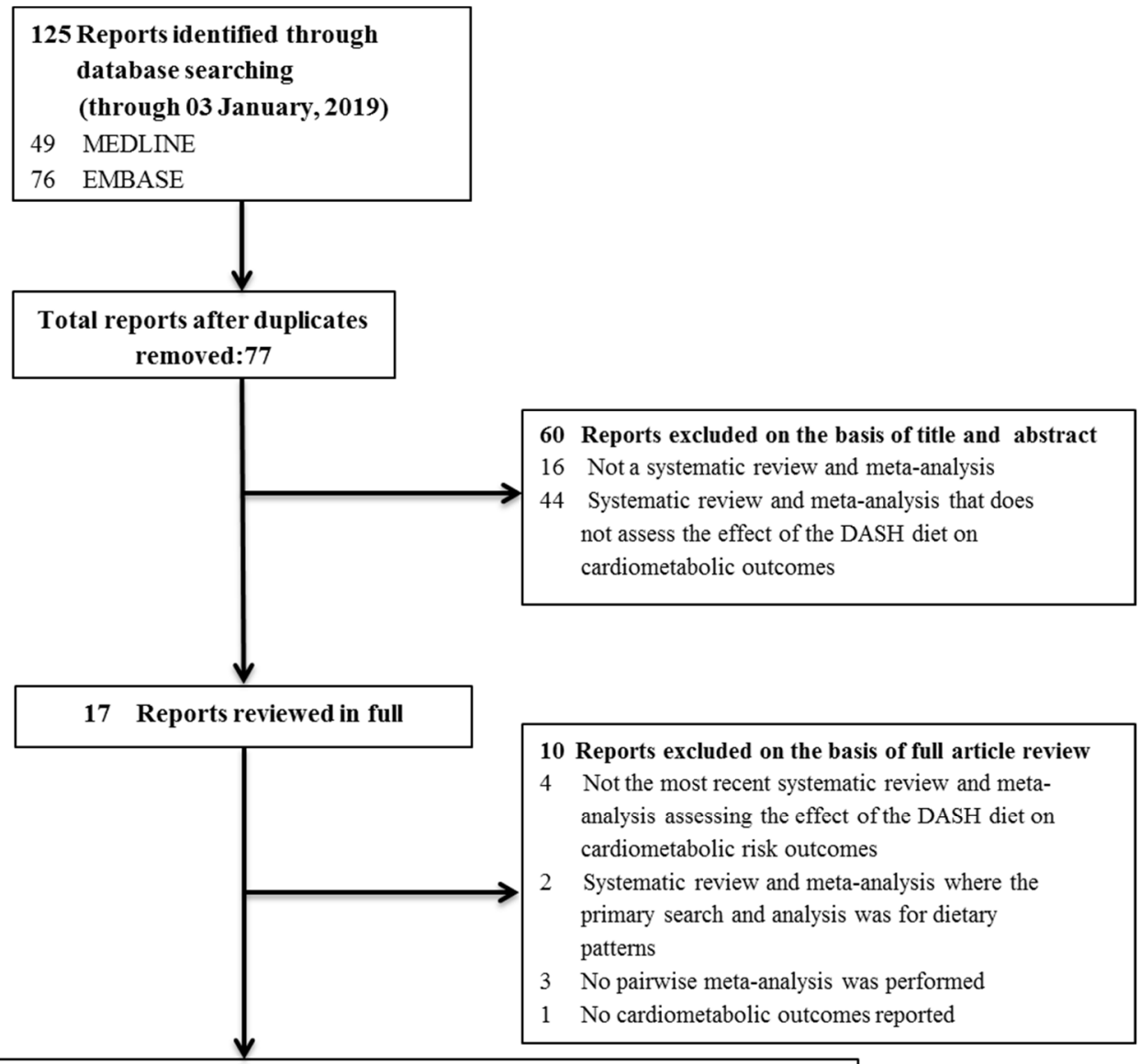

7 Reports included in the review:

3 Systematic reviews and meta-analyses of prospective cohort studies:

1 Including composite CVD outcomes

1 Including stroke incidence

1 Including diabetes incidence

1 Including overall mortality

4 Systematic reviews and meta-analyses of randomized controlled trials:

0 Including $\mathrm{HbAlc}$

2 Including glycemic control outcomes

1 Including blood pressure outcomes

1 Including blood lipid outcomes

1 Including body weight and adiposity outcomes

1 Including inflammatory outcomes

Figure 1. Literature search.

Supplemental Table S5 shows the GRADE assessment of the certainty of the evidence for the relationship between the DASH dietary pattern and CVD. The evidence was rated as low for the association of the DASH dietary pattern and CVD incidence. This assessment suggests that the DASH dietary pattern may have a meaningful cardiovascular benefit, but the estimate remains uncertain. 
Table 1. Summary of characteristics of included studies in most recent systematic reviews and meta-analyses of prospective cohort studies assessing the effect of the DASH dietary pattern on chronic disease.

\begin{tabular}{|c|c|c|c|c|c|c|c|c|c|c|c|c|c|c|}
\hline 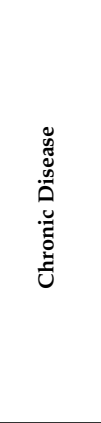 & 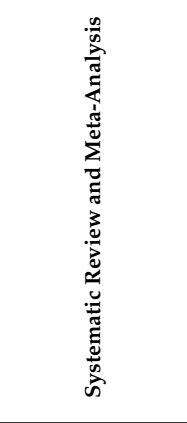 & 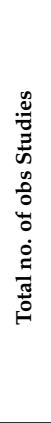 & 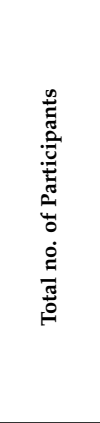 & 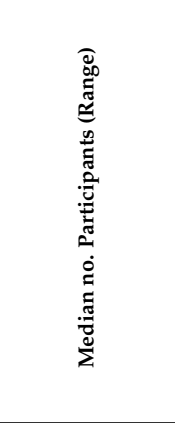 & 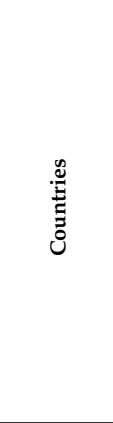 & 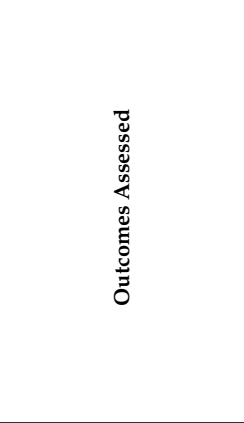 & 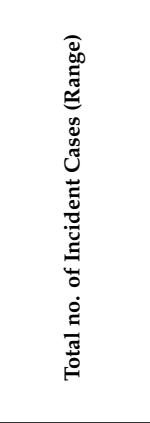 & 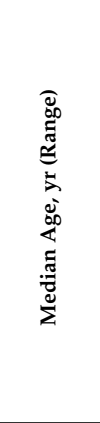 & 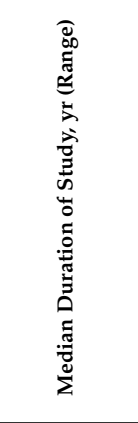 & 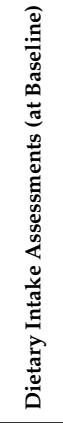 & 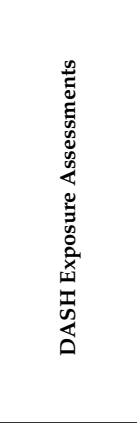 & 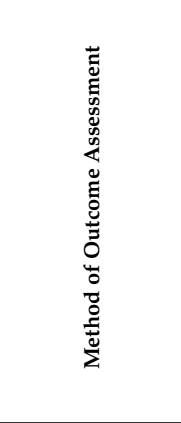 & 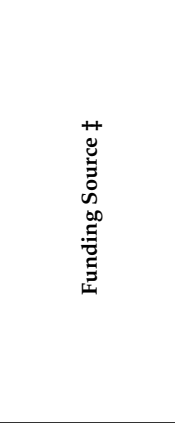 & 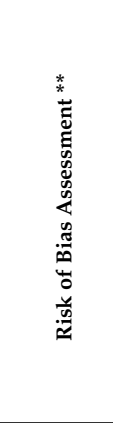 \\
\hline CVD & $\begin{array}{l}\text { Schwingshackl } \\
\text { et al., } 2015 \text { [13] }\end{array}$ & 11 & 783,732 & $\begin{array}{c}44,544 \\
(2061-242,321)\end{array}$ & $\begin{array}{l}7 \text { USA: } 2 \\
\text { Sweden: } \\
1 \text { Italy: } 1 \\
\text { China }\end{array}$ & $\begin{array}{l}\text { 3 CHD incidence: } 3 \\
\text { CVD mortality: } 3 \\
\text { stroke incidence: } 1 \\
\text { CVD incidence: } 1 \\
\text { sudden cardiac death } \\
1 \text { CHD morbidity and }\end{array}$ & $\begin{array}{c}32,927 \\
(123-15,497)\end{array}$ & $\begin{array}{c}60.5 \\
(20-83)\end{array}$ & $14.6(7.9-24)$ & FFQ & $\begin{array}{l}7 \text { quintiles: } \\
2 \text { quartiles: } \\
2 \text { tertiles of } \\
\text { DASH score }\end{array}$ & Record linkage & $\begin{array}{l}8 \text { Agency: } 2 \text { not } \\
\text { reported: } 1 \\
\text { Agency, } \\
\text { Industry }\end{array}$ & $10 \mathrm{H}: 1 \mathrm{Lo}$ \\
\hline CHD & $\begin{array}{l}\text { Salehi-Abargouei } \\
\text { et al., 2013 [43] }\end{array}$ & 3 & 144,337 & $\begin{array}{c}348,827 \\
(20,993-88,517)\end{array}$ & 3 USA & $\begin{array}{l}\text { mortality: } 1 \text { CHD } \\
\text { mortality: } 1 \text { fatal and } \\
\text { nonfatal CHD }\end{array}$ & $\begin{array}{c}7260 \\
(430-6210)\end{array}$ & $\begin{array}{c}52 \\
(30-69)\end{array}$ & $16(14.6-24)$ & FFQ & 3 quintiles & Record linkage & 3 Agency & $2 \mathrm{H}: 1 \mathrm{Lo}$ \\
\hline Stroke & $\begin{array}{l}\text { Salehi-Abargouei } \\
\text { et al., 2013 [43] }\end{array}$ & 3 & 150,191 & $\begin{array}{c}40,681 \\
(20,993-88,517)\end{array}$ & $\begin{array}{l}2 \text { USA: } 1 \\
\text { Italy }\end{array}$ & $\begin{array}{l}1 \text { stroke incidence: } 1 \\
\text { stroke mortality: } 1 \text { fatal } \\
\text { and nonfatal stroke }\end{array}$ & $\begin{array}{c}4,413 \\
(178-3999)\end{array}$ & $\begin{array}{c}52 \\
(30-74)\end{array}$ & $16(7.9-24)$ & FFQ & $\begin{array}{l}2 \text { quintiles: } \\
1 \text { tertiles }\end{array}$ & Record linkage & $\begin{array}{l}2 \text { Agency: } 1 \\
\text { Agency, } \\
\text { Industry }\end{array}$ & $2 \mathrm{H}: 1 \mathrm{Lo}$ \\
\hline Diabetes & $\begin{array}{l}\text { Jannasch } \\
\text { et al., } 2017 \text { [12] }\end{array}$ & 5 & 158,408 & $\begin{array}{c}21,616 \\
(822-89,195)\end{array}$ & $\begin{array}{l}4 \text { US: } 1 \\
\text { Europe } \\
(8 \\
\text { countries })\end{array}$ & diabetes incidence & $\begin{array}{c}23,612 \\
(129-11,217)\end{array}$ & $\begin{array}{c}58 \\
(25-84)\end{array}$ & $11.5(5-20)$ & FFQ & $\begin{array}{l}4 \text { quintiles: } \\
1 \text { tertiles }\end{array}$ & $\begin{array}{l}3 \text { self-reported + } \\
\text { record linkage: } 1 \\
\text { independent } \\
\text { assessment: } 1 \\
\text { OGTT or DM } \\
\text { med use }\end{array}$ & $\begin{array}{l}4 \text { Agency: } 1 \\
\text { Agency, } \\
\text { Industry }\end{array}$ & $4 \mathrm{H}: 1 \mathrm{Lo}$ \\
\hline
\end{tabular}

$\ddagger$ Agency funding is that from government, university or not-for-profit health agency sources. ${ }^{* *}$ Newcastle Ottawa quality assessment Scale was used to assess risk of bias across the following domains: selection (four points), comparability (two points), and outcome (three points). A total score of six or greater was considered high-quality and a total score of five or smaller was considered low-quality. CHD, coronary heart disease; CVD, cardiovascular disease; obs, prospective cohort; DASH, dietary approaches to stop hypertension; DM, diabetes; $\mathrm{H}$ High; Lo, Low; med, medication; obs, observational; OGTT, oral glucose tolerance test; yr, year 


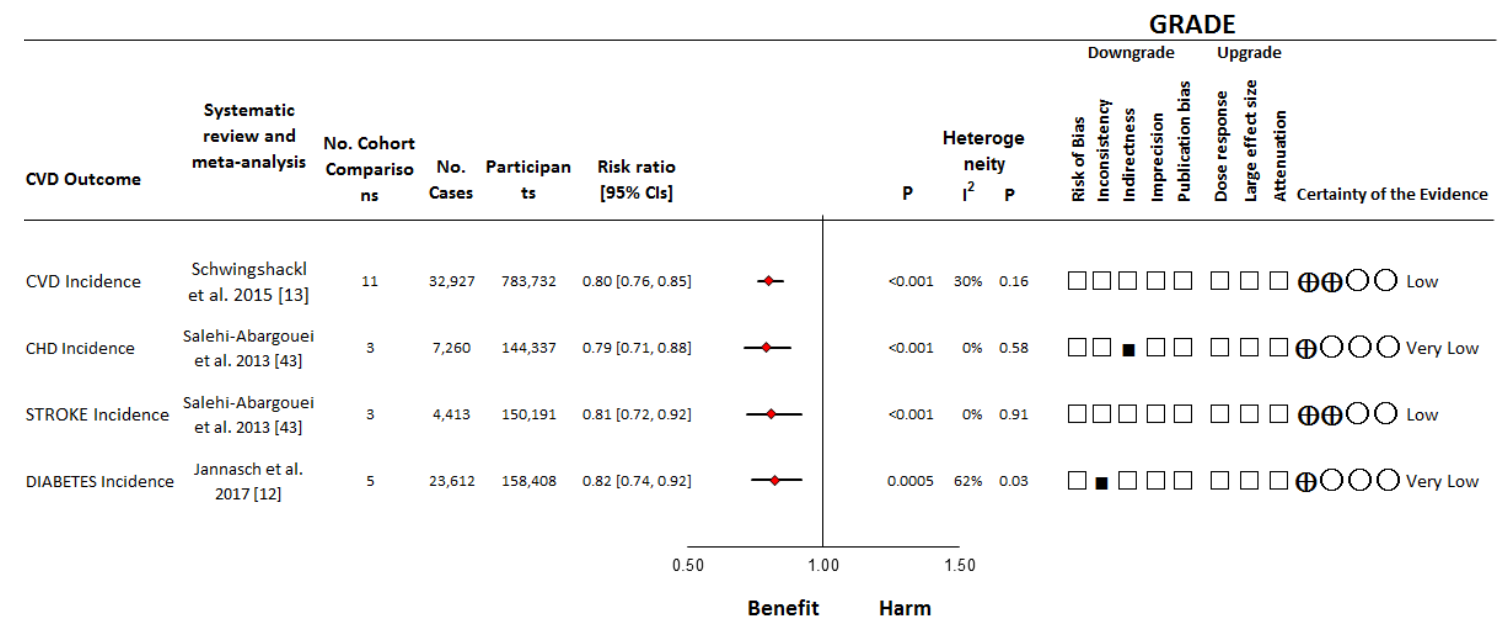

Figure 2. Summary plot of the association between the DASH dietary pattern on risk of various chronic diseases in prospective cohort studies. The pooled risk estimate is represented by the diamond. $\mathrm{P}$-values were determined using random effects modelling in each systematic review and meta-analysis. Between-study heterogeneity was assessed by the Cochran $Q$ statistic, where $P<0.10$ is considered statistically significant, and quantified by the $\mathrm{I}^{2}$ statistic, where $\mathrm{I}^{2} \geq 50 \%$ is considered evidence of substantial heterogeneity [29]. The Grading of Recommendations, Assessment, Development and Evaluation (GRADE) of prospective cohort studies are rated as "Low" certainty of evidence and can be downgraded by five domains and upgraded by three domains. The filled black squares indicate downgrade and/or upgrades for each outcome. $\mathrm{CHD}=$ coronary heart disease; $\mathrm{CI}$ = confidence interval; $\mathrm{CVD}=$ cardiovascular disease; GRADE = Grading of Recommendations, Assessment, Development and Evaluation; NA = not applicable.

Coronary Heart Disease Incidence

One systematic review and meta-analysis assessed the relationship between consumption of the DASH dietary pattern and CHD incidence [43] (Figure 2, Table 1, and Supplemental Table S6). It included three prospective cohort comparisons [37-39] ( $n=144,337 ; 7260$ events) all of which were conducted in the United States, with follow-up durations ranging from 14.6 to 24 years [43]. The consumption of a DASH dietary pattern was found to significantly reduce CHD incidence $\left(\mathrm{RR}=0.79\right.$ (95\% CI: 0.71-0.88)), which showed no evidence of inter-study heterogeneity $\left(\mathrm{I}^{2}=0 \%\right)[43]$. No serious risk of bias was identified (Supplemental Tables S7-S8).

Supplemental Table S5 shows the GRADE assessment of the overall strength of the evidence for the relationship between the DASH dietary pattern and CHD incidence. The evidence was rated as very low for the association of the DASH dietary pattern and CHD incidence, owing to a downgrade for indirectness since the findings are not generalizable given that the three prospective cohort studies were conducted in middle-aged or elderly women. The relationship remains uncertain, with future studies likely to have an important influence on risk estimates.

Stroke Incidence

One systematic review and meta-analysis assessed the relationship between consumption of the DASH dietary pattern and stroke incidence [43] (Figure 2, Table 1 and Supplemental Table S9). It included three prospective cohort comparisons [35,38,39] ( $n=150,191 ; 4,413$ events) two of which were conducted in the United States and one study in Italy, with follow-up durations ranging from 7.9-24 years [43]. The consumption of a DASH dietary pattern was found to significantly reduce stroke incidence (RR $=0.81$ (95\% CI: 0.72-0.92)), which showed no evidence of inter-study heterogeneity $\left(\mathrm{I}^{2}=0 \%\right)$ [43]. No serious risk of bias was identified (Supplemental Tables S10-S11).

Supplemental Table S5 shows the GRADE assessment of the certainty of the evidence for the relationship between the DASH dietary pattern and stroke incidence. The evidence was rated as low 
for the association of the DASH dietary pattern and stroke incidence. This assessment suggests that the DASH dietary pattern may have a meaningful stroke benefit, but the estimate remains uncertain.

Diabetes Incidence

One systematic review and meta-analysis assessed the relationship between consumption of the DASH dietary pattern and diabetes incidence [12] (Figure 2, Table 1, and Supplemental Table S12). It included five prospective cohort studies [44-48] ( $n=158,408 ; 23,612$ events) four of which were conducted in the United States and one study in Europe, with follow-up durations ranging from 5-20 years [12]. The consumption of a DASH dietary pattern was found to significantly reduce diabetes incidence $(\mathrm{RR}=0.82$ (95\% CI: 0.74-0.92)), however showed substantial unexplained inter-study heterogeneity $\left(\mathrm{I}^{2}=62 \%\right)$ [12]. No serious risk of bias was identified (Supplemental Tables S13-S14).

Supplemental Table S5 shows the GRADE assessment of the certainty of the evidence for the relationship between the DASH dietary pattern and diabetes incidence. The evidence was rated as very low for the association of the DASH dietary pattern and diabetes incidence, owing to a downgrade for inconsistency $\left(\mathrm{I}^{2}=62 \% ; P=0.03\right)$, and with $<10$ studies, no subgroup analyses were performed to attempt to explain heterogeneity. The relationship remains uncertain, with future studies likely to have an important influence on risk estimates.

\subsubsection{Systematic Reviews and Meta-analyses of Controlled Trials}

\section{Blood Pressure}

One systematic review and meta-analysis of controlled trials assessed the effect of the DASH dietary pattern on blood pressure outcomes, including SBP and DBP [11] (Figure 3, Table 2, and Supplemental Table S15). A total of nineteen controlled trials [10,49-63] were included, involving 1,918 middle-aged participants with and without hypertension. The DASH dietary pattern was found to significantly lower SBP (MD $=-5.20 \mathrm{mmHg}(95 \% \mathrm{CI}:-7.00$ to $-3.40 \mathrm{mmHg})$ ) and DBP $(\mathrm{MD}=-2.60 \mathrm{mmHg}(95 \% \mathrm{CI}:-3.50$ to $-1.70 \mathrm{mmHg}))$. There was substantial unexplained inter-study heterogeneity across both outcomes ( $\mathrm{I}^{2}=76 \%$ and $49 \%$, respectively). No serious risk of bias was identified (Supplemental Figures S1-S2).

Supplemental Table S16 shows the GRADE assessments for the certainty of the evidence for the effect of a DASH dietary pattern on blood pressure. The evidence for SBP was rated as moderate, owing to a downgrade for inconsistency $\left(\mathrm{I}^{2}=76 \% ; P<0.001\right)$. The evidence for DBP was rated as low, owing to downgrades for inconsistency $\left(\mathrm{I}^{2}=49 \% ; P=0.009\right)$ and imprecision in the pooled effect estimate. This assessment suggests that the DASH dietary pattern may result in clinically meaningful reductions in blood pressure. The effect of the DASH dietary pattern on DBP, however, remains uncertain, with future randomized controlled trials likely to have an important influence on risk estimates. 


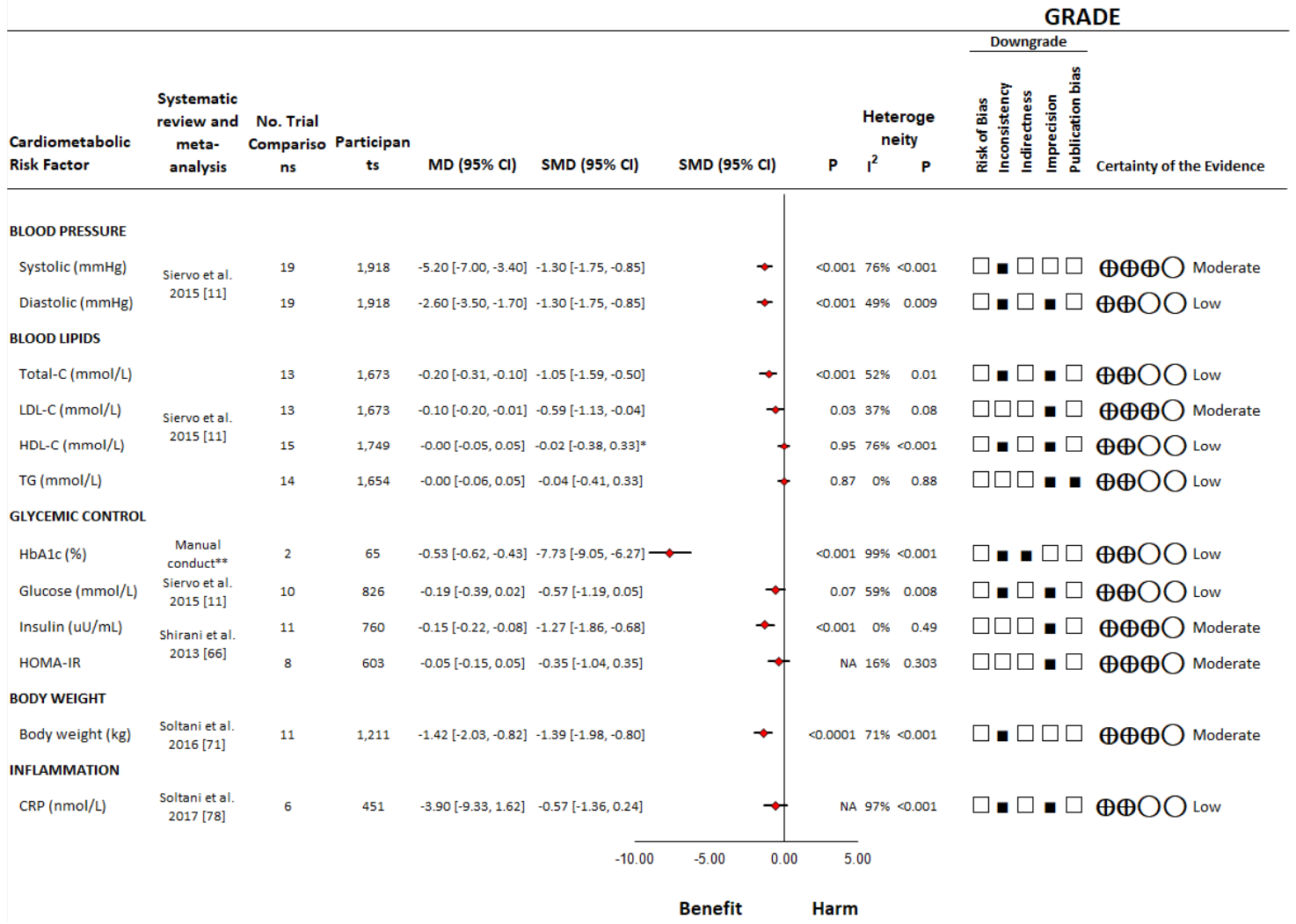

Figure 3. Summary plot of the effect of the DASH dietary pattern on cardiometabolic risk factors in controlled trials. Data are expressed as weighted mean differences with $95 \%$ CIs using random effects models in each systematic review and meta-analysis with the exception of $\mathrm{HbA} 1 \mathrm{c}$ in which a fixed effects model was used due to the inclusion of $<5$ trials. To allow the pooled effect estimates for each end point to be displayed on the same axis, mean differences were transformed to standardized mean differences (SMDs). Pseudo-95\% CIs for each transformed SMD were derived directly from the original mean difference and $95 \%$ CI. Between-study heterogeneity was assessed by the Cochran $Q$ statistic, where $P<0.10$ is considered statistically significant, and quantified by the $\mathrm{I}^{2}$ statistic, where $\mathrm{I}^{2}$ $\geq 50 \%$ is considered evidence of substantial heterogeneity [29]. The Grading of Recommendations, Assessment, Development and Evaluation (GRADE) of randomized controlled trials are rated as "High" certainty of evidence and can be downgraded by five domains. The filled black squares indicate downgrades for each outcome. *Due to the difference in directionality of HDL-C compared to the other outcomes with regards to signal for benefit or harm, the sign for the SMD was changed. ** Since no published systematic review and meta-analysis was retrieved from the search, we manually conducted a systematic review and meta-analysis on the DASH dietary pattern and HbA1c (Supplemental Tables S20-21 and Supplemental Figure S3). To convert Total-C, LDL-C, and HDL-C to mg/dL, multiply by 38.67 ; to convert TG to $\mathrm{mg} / \mathrm{dL}$, multiply by 88.57 ; to convert blood glucose to $\mathrm{mg} / \mathrm{dL}$, multiply by 18.02; to convert $\mathrm{CRP}$ to $\mathrm{mg} / \mathrm{L}$, multiply by 0.105 . $\mathrm{CI}=$ confidence interval; $\mathrm{CRP}=\mathrm{C}$-reactive protein; GRADE = Grading of Recommendations, Assessment, Development and Evaluation; HbA1c = hemoglobin A1c; HDL-C = high-density lipoprotein-cholesterol; HOMA-IR = Homeostatic Model Assessment of Insulin Resistance; LDL-C = low-density lipoprotein-cholesterol; MD = mean difference; $\mathrm{NA}=$ not available; $\mathrm{SMD}=$ standardized mean difference; $\mathrm{TG}=$ triglycerides; Total- $\mathrm{C}=$ total-cholesterol 
Table 2. Summary of characteristics of included trials in the most recent systematic reviews and meta-analyses of controlled trials assessing the effect of the DASH dietary pattern on cardiometabolic risk factors.

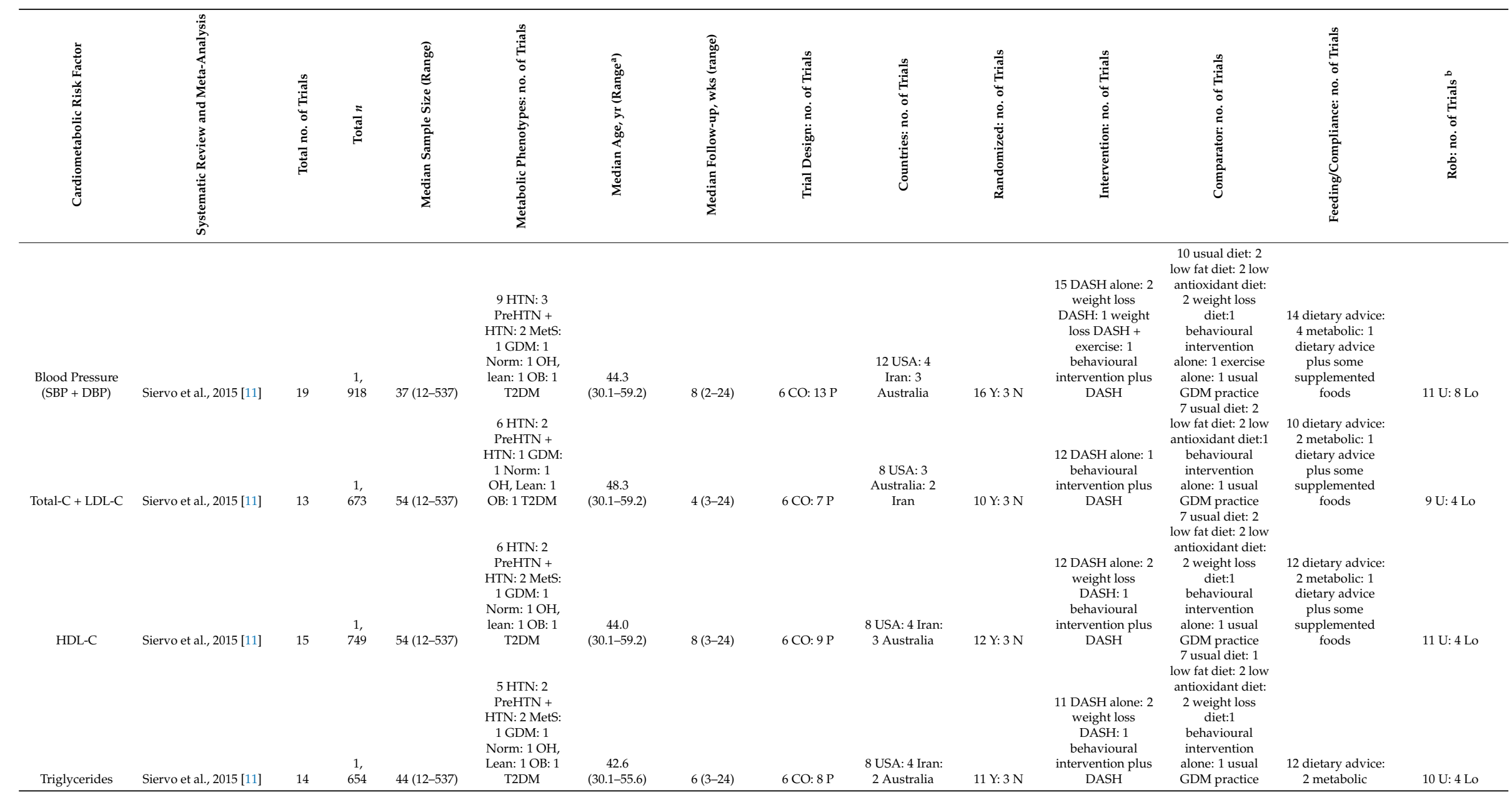


Table 2. Cont.

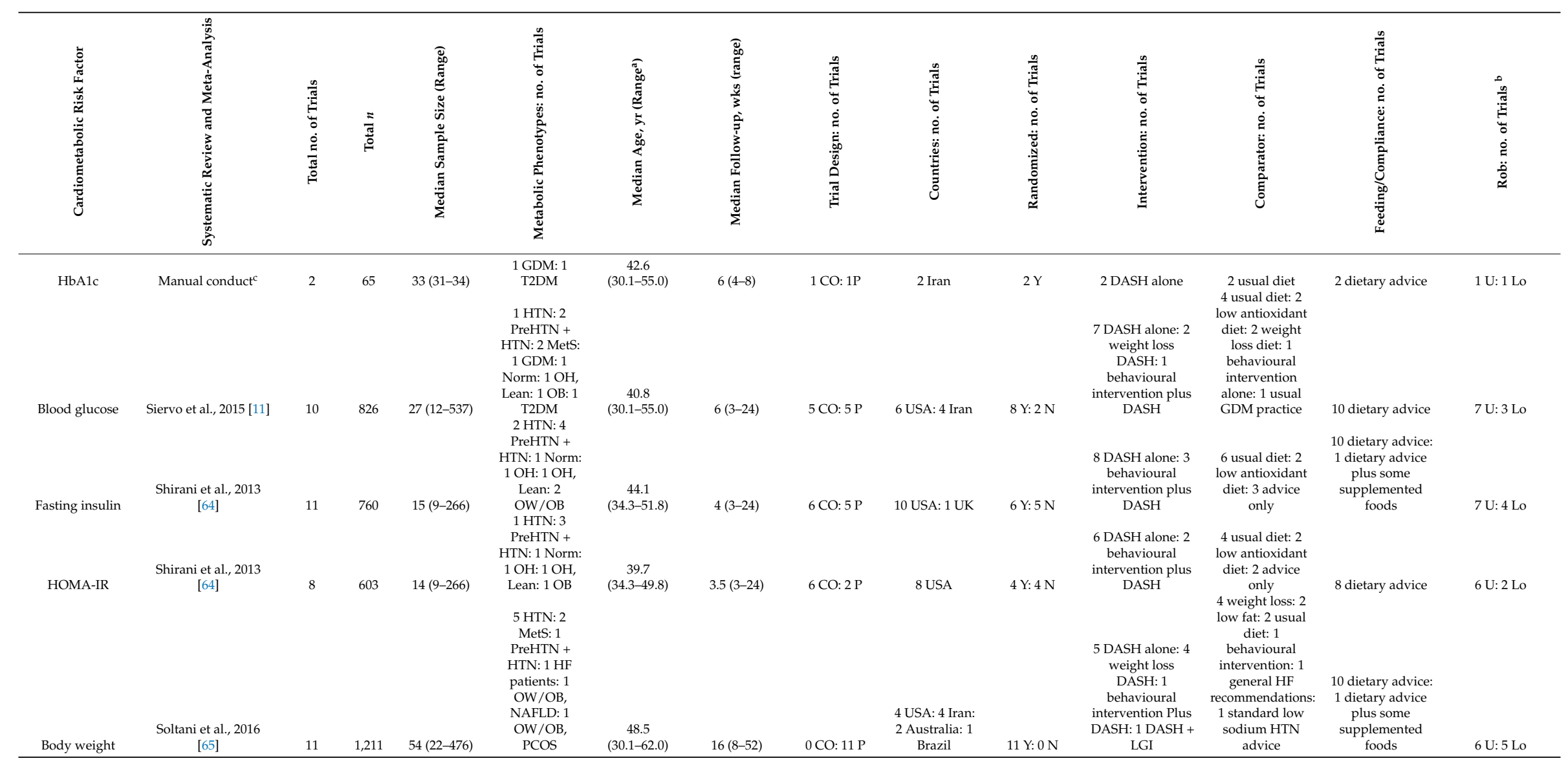


Table 2. Cont.

\begin{tabular}{|c|c|c|c|c|c|c|c|c|c|c|c|c|c|c|}
\hline 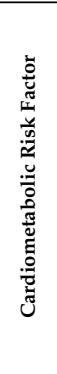 & 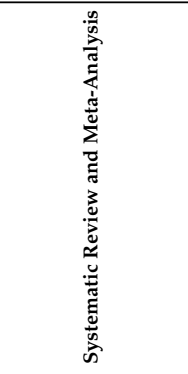 & 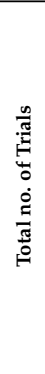 & 苞 & 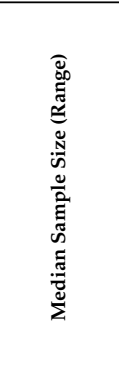 & 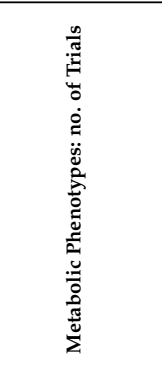 & 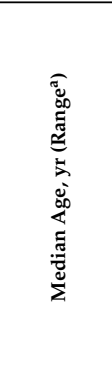 & 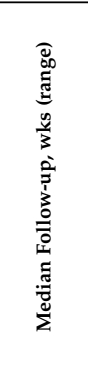 & 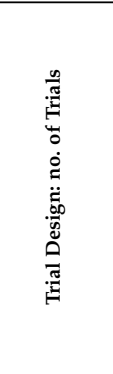 & 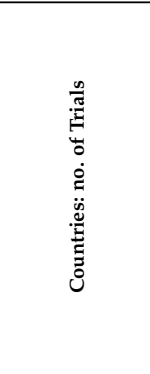 & 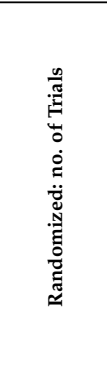 & 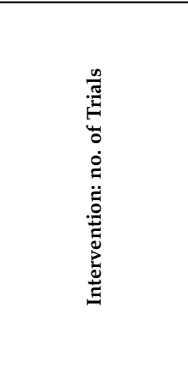 & 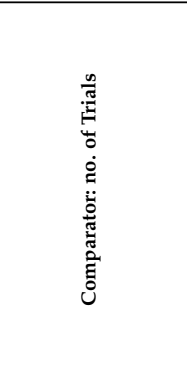 & 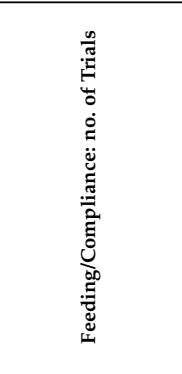 & 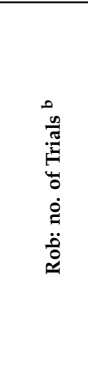 \\
\hline CRP & $\begin{array}{c}\text { Soltani et al., } 2017 \\
{[66]}\end{array}$ & 6 & 451 & $42(31-241)$ & $\begin{array}{l}2 \\
\text { Hyperlipidemic: } \\
\text { 1 Lean Norm } \\
\text { +OB HTN: } 1 \\
\text { OW/OB, } \\
\text { NAFLD: } 1 \\
\text { OW/OB, } \\
\text { PCOS: 1 } \\
\text { T2DM }\end{array}$ & $\begin{array}{c}45.7 \\
(30.1-55.0)\end{array}$ & $8(3-24)$ & $3 \mathrm{CO} 3 \mathrm{P}$ & $\begin{array}{l}3 \text { Iran: } 2 \text { USA: } \\
1 \text { Canada }\end{array}$ & $16 Y: 0 \mathrm{~N}$ & $\begin{array}{l}\text { 3 DASH alone: } 2 \\
\text { weight loss } \\
\text { DASH: } 1 \\
\text { lacto-ovo } \\
\text { vegetarian DASH }\end{array}$ & $\begin{array}{l}2 \text { weight loss: } 1 \\
\text { usual diet: } 1 \\
\text { usual plus fibre, } \\
\text { potassium, } \\
\text { magnesium: } 1 \\
\text { healthy } \\
\text { American: } 1 \\
\text { Portfolio diet } \\
\text { (plant-based with } \\
\text { soy protein, } \\
\text { viscous fibres and } \\
\text { nuts) }\end{array}$ & $\begin{array}{l}15 \text { dietary advice: } \\
1 \text { metabolic }\end{array}$ & $3 \mathrm{U}: 3 \mathrm{Lo}$ \\
\hline
\end{tabular}

A range represents the range of the mean age in the trials. $b$ For ROB, an assessment was performed using the Cochrane Risk of Bias tool, including the evaluation of individual domains of risk of bias (sequence generation, allocation concealment, blinding of participants/personnel and outcome assessors, incomplete outcome data, selective outcome reporting). Each of the five domains was evaluated as either low, high or unclear ROB and the overall ROB category was determined based on the most selected category. c Since no published systematic review and meta-analysis was retrieved from the search, we manually conducted a systematic review and meta-analysis on the DASH dietary pattern and HbA1c (Supplemental Tables S20-21 and Supplemental Figure S3). BMI, body mass index; BP, blood pressure; CO, crossover; CRP, C-reactive protein; DASH, dietary approaches to stop hypertension; DBP, diastolic blood pressure; DM, diabetes; F, female; F/U, follow-up; GDM, gestational diabetes; HDL-C, high-density lipoprotein-cholesterol; HF, heart failure; HTN, hypertensive; HOMA-IR, Homeostatic Model Assessment of Insulin Resistance; HTN, hypertension; L, lean; Lo, Low; LDL-C, low-density lipoprotein-cholesterol; LGI, low glycemic index; M, male; meds, medication; MetS, metabolic syndrome; N, no; Norm, normotensive; NAFLD, non-alcoholic fatty liver disease; OB, obese; OH, overall healthy; OW, overweight; P, parallel; PCOS, polycystic ovarian metabolic syndrome; N, no; Norm, normotensive; NAFLD, non-alcoholic fatty liver disease; OB, obese; OH, overall healthy; OW, overweight; P, parallel; PCOS, polycystic ovarian
syndrome; PreHTN, prehypertensive; ROB, Risk of Bias; SBP, systolic blood pressure; SD, standard deviation; T2DM, type 2 diabetes; Total-C, total-cholesterol; U, unclear; W, women; wks, syndrome; PreHTN, pre
weeks; Y, yes; yr; year. 


\section{Blood Lipids}

One systematic review and meta-analysis of controlled trials assessed the effect of the DASH dietary pattern on blood lipid outcomes, including Total-C, LDL-C, HDL-C and triglycerides [11] (Figure 3, Table 2, and Supplemental Tables S17-S19). A total of thirteen controlled trials $[50,52-55,57-59,63,67,68]$ were included in the analysis of Total-C and LDL-C, involving 1673 middle-aged participants, fifteen trials $[50,52-59,63,67,68]$ in the analysis of HDL-C, involving 1749 participants, and 14 trials $[50,52,54-59,63,67,68]$ in the analysis of triglycerides, involving 1654 participants. The DASH dietary pattern was found to lower Total-C (MD $=-0.20 \mathrm{mmol} / \mathrm{L}(95 \%$ CI: -0.31 to $-0.10 \mathrm{mmol} / \mathrm{L})$ ) and LDL-C (MD $=-0.10 \mathrm{mmol} / \mathrm{L}(95 \% \mathrm{CI}:-0.20$ to $-0.01 \mathrm{mmol} / \mathrm{L})$ ) with no significant effects on HDL-C or triglycerides. There was substantial unexplained inter-study heterogeneity for Total-C and HDL-C ( $\mathrm{I}^{2}=52 \%$ and $76 \%$, respectively), some evidence of inter-study heterogeneity for LDL-C $\left(\mathrm{I}^{2}=37 \%\right)$ and no evidence of inter-study heterogeneity for triglycerides $\left(\mathrm{I}^{2}=0 \%\right)$. No serious risk of bias was identified (Supplemental Figures S1-S2).

Supplemental Table S16 shows the GRADE assessments for the certainty of the evidence for the effect of a DASH dietary pattern on blood lipids. The evidence for LDL-C was rated as moderate, owing to a downgrade for imprecision in the pooled effect estimate. The evidence for Total-C, HDL-C, and triglycerides were rated as low, where Total-C and HDL-C were downgraded for inconsistency $\left(\mathrm{I}^{2}=52 \%\right.$ and $76 \%$, respectively) and imprecision in the pooled effect estimates and triglycerides was downgraded for imprecision in the pooled effect estimate and for evidence of potential publication bias. This assessment suggests that the DASH dietary pattern may result in reductions in Total-C and LDL-C, established therapeutic lipid targets for cardiovascular risk reduction. However, sources of uncertainty remain. Thus, there is a need for further large, high quality, randomized controlled trials to clarify the lipid-lowering benefits of the DASH dietary pattern.

\section{Glycemic Control}

There were no systematic reviews and meta-analyses identified of trials assessing the effect of the DASH dietary pattern on HbA1c. Therefore, we conducted a systematic review and meta-analysis for this outcome. The search (Supplemental Table S20) identified 2 controlled trials [57,63] (Supplemental Figure S3) which were eligible for inclusion, involving 65 middle-aged participants. The DASH dietary pattern was found to lower $\mathrm{HbA} 1 \mathrm{c}(\mathrm{MD}=-0.53 \%(95 \% \mathrm{CI}:-0.62$ to $-0.43 \%)$ with significant evidence of inter-study heterogeneity $\left(I^{2}=99 \%\right.$ ) (Figure 3, Table 2, and Supplemental Table S21).

One systematic review and meta-analysis of controlled trials assessed the effect of the DASH dietary pattern on blood glucose [11], insulin, and HOMA-IR [64] (Figure 3, Table 2, and Supplemental Tables S22-S24). A total of ten controlled trials $[50,52,56-59,63]$ were included in the analysis of blood glucose, involving 826 middle-aged participants, 11 trials [52,58,59,69-72] in the analysis of insulin, involving 760 participants, and eight trials $[52,58,70,71]$ in the analysis of HOMA-IR, involving 603 participants. The DASH dietary pattern was found to lower insulin (MD $=-0.15 \mu \mathrm{U} / \mathrm{mL}(95 \% \mathrm{CI}$ : -0.22 to $-0.08 \mu \mathrm{U} / \mathrm{mL})$ ) with no significant effects on blood glucose or HOMA-IR. There was no evidence of inter-study heterogeneity for insulin $\left(\mathrm{I}^{2}=0 \%\right)$ or for HOMA-IR $\left(\mathrm{I}^{2}=16 \%\right)$. There was substantial unexplained inter-study heterogeneity for blood glucose $\left(\mathrm{I}^{2}=59 \%\right)$ No serious risk of bias was identified (Supplemental Figures S1-S2).

Supplemental Table S16 shows the GRADE assessments for the certainty of the evidence for the effect of a DASH dietary pattern on glycemic control. The evidence for $\mathrm{HbA1} \mathrm{c}$ was rated as low, owing to downgrades for inconsistency $\left(\mathrm{I}^{2}=99 \%\right)$ and serious indirectness due to $<5$ studies available for inclusion and lack of generalizability since one study included those with type 2 diabetes and the other women with gestational diabetes. The evidence for blood glucose was also rated as low, owing to downgrades for inconsistency $\left(\mathrm{I}^{2}=59 \%\right)$ and imprecision in the pooled effect estimate. The evidence for fasting insulin and HOMA-IR were rated as moderate, owing to downgrades for imprecision in the pooled effect estimates. This assessment suggests that the DASH dietary pattern may result in 
reductions in $\mathrm{HbA1c}$. The effect estimates, however, remain uncertain for most glycemic outcomes, calling for more large, high-quality, randomized trials to clarify the glycemic benefits.

Body Weight

One systematic review and meta-analysis of controlled trials assessed the effect of the DASH dietary pattern on body weight [65] (Figure 3, Table 2, and Supplemental Table S25). A total of 11 controlled trials $[53,55,56,59,73-78]$ were included in the analysis of body weight, involving 1211 middle-aged participants. The DASH dietary pattern was found to lower body weight $(\mathrm{MD}=-1.42 \mathrm{~kg}(95 \% \mathrm{CI}:-2.03$ to $-0.82 \mathrm{~kg}))$. There was substantial unexplained inter-study heterogeneity for body weight $\left(\mathrm{I}^{2}=71 \%\right)$. No serious risk of bias was identified (Supplemental Figures S1-S2).

Supplemental Table S16 shows the GRADE assessments for the certainty of the evidence for the effect of a DASH dietary pattern on body weight. The evidence for body weight was rated as moderate, owing to a downgrade for inconsistency $\left(\mathrm{I}^{2}=71 \%\right)$. This assessment suggests that the DASH dietary pattern may result in meaningful reductions in body weight. The relationship, however, remains uncertain, with future randomized controlled trials likely to have an important influence on risk estimates.

\section{Inflammation}

One systematic review and meta-analysis of controlled trials assessed the effect of the DASH dietary pattern on inflammation [66] (Figure 3, Table 2, and Supplemental Table S26). A total of six controlled trials $[57,77-81]$ were included in the analysis of the inflammatory marker C-reactive protein (CRP), involving 451 middle-aged participants. The DASH dietary pattern was found not to have an effect on CRP. There was substantial unexplained inter-study heterogeneity for CRP $\left(\mathrm{I}^{2}=97 \%\right)$. However, subgroup analyses performed by Soltani et al. [66] based on comparator revealed a significant effect compared to unhealthy or usual diets ( 4 studies) $((\mathrm{MD}=-9.62 \mathrm{nmol} / \mathrm{L}(95 \% \mathrm{CI}:-15.62$ to -3.62 $\mathrm{nmol} / \mathrm{L}), \mathrm{I}^{2}=67.7 \%$ ), as well as based on follow-up where there was an effect in trials with $\geq 8$ weeks follow-up ((MD = $-7.05 \mathrm{nmol} / \mathrm{L}(95 \% \mathrm{CI}:-12.95$ to $\left.-1.05 \mathrm{nmol} / \mathrm{L}), \mathrm{I}^{2}=92.7 \%\right)$. No serious risk of bias was identified (Supplemental Figures S1-S2).

Supplemental Table S16 shows the GRADE assessments for the certainty of the evidence for the effect of a DASH dietary pattern on CRP. The evidence for CRP was rated as low, owing to downgrades for inconsistency $\left(\mathrm{I}^{2}=97 \%\right)$ and imprecision in the pooled effect estimate. This assessment suggests uncertainty in whether the DASH dietary pattern has an effect on inflammation. Future randomized controlled trials are likely to have an important influence on risk estimates.

\section{Discussion}

The present umbrella review of the DASH dietary pattern and cardiometabolic outcomes identified three systematic reviews and meta-analyses of prospective cohort studies involving 15 unique cohort comparisons in 942,140 participants and 32,927 CVD events, 7260 CHD events, 4413 stroke events, 23,612 diabetes events, and four systematic reviews and meta-analyses supplemented by one updated systematic review and meta-analysis of randomized and non-randomized controlled trials involving 33 trial comparisons in 4479 participants on intermediate cardiometabolic risk factors. The DASH dietary pattern was associated with a reduction in the primary outcome of the prospective cohort studies, CVD incidence (20\%), as well as reductions in the secondary outcomes: CHD (21\%), stroke $(19 \%)$, and diabetes $(18 \%)$. These changes were supported by a clinically meaningful reduction in the primary outcome of the controlled trials, blood pressure $(-5.2 \mathrm{mmHg}$ for SBP), as well as reductions in the secondary outcomes: DBP $(-2.6 \mathrm{mmHg})$, lipids $(-0.1 \mathrm{mmol} / \mathrm{L}$ for LDL-C and $-0.2 \mathrm{mmol} / \mathrm{L}$ for Total-C), body weight $(1.42 \mathrm{~kg})$, and $\mathrm{HbA} 1 \mathrm{c}(-0.53 \%)$. 


\subsection{Findings in the Context of the Literature}

The observed cardiovascular benefits may be attributable to a combination of the foods encouraged as part of the DASH dietary pattern. High consumption of fruits and vegetables as part of the DASH dietary pattern have been shown in systematic reviews and meta-analyses of prospective cohort studies, when consumed either together or alone, to be inversely associated with cardiovascular incidence and mortality [82]. Systematic reviews and meta-analyses of prospective cohort studies have also demonstrated that whole grain intake is associated with a $20-21 \%$ reduction in CVD incidence [83,84] and 14\% reduction in stroke incidence [84], dietary pulse intake with a $9 \%$ reduction in CVD incidence [85], and nut intake with a $21 \%$ reduction per $28 \mathrm{~g} /$ day [86], while processed and red meats are associated with a $15-18 \%$ increase in incidence of CVD mortality comparing highest to lowest levels of intake $[87,88]$. A key nutrient richly found in many of the foods emphasized which may contribute a biological effect includes dietary fibre, which has been shown in systematic reviews and meta-analyses of prospective cohort studies to reduce CVD by $9 \%$ per $7 \mathrm{~g} / \mathrm{d}$ intake [89] and reduced risks of CHD and stroke incidence of $24 \%$ and $22 \%$, respectively, when comparing highest to lowest intake groups [84], in addition to significant reductions in body weight, Total-C, LDL-C, and SBP in controlled clinical trials [84]. CVD benefit may be the result of the biological effects of other key nutrients richly found in foods emphasized in the DASH dietary pattern, such as magnesium, potassium, and phytochemicals, including flavonoids, which have been demonstrated to have anti-inflammatory and anti-antioxidant activity and result in reductions in angiogenesis $[56,90,91]$. The blood pressure lowering effect of the DASH diet may play a major role, since high blood pressure is ranked as the strongest risk factor attributable to chronic disease [10,92]. Furthermore, the observed 5.20-mmHg lowering in SBP by the DASH dietary pattern is clinically relevant based on evidence from prospective studies showing that a $2-\mathrm{mmHg}$ reduction in SBP is associated with lower mortality from stroke $(10 \%)$ and CHD or other vascular causes $(7 \%)$ in middle-aged men and women [93]. An additional contribution may be via a reduction in established therapeutic lipid targets for cardiovascular risk [11], such as the observed $0.10 \mathrm{mmol} / \mathrm{L}$ lowering in LDL-C, which would translate to about a $2 \%$ reduction in major cardiovascular events based on the Cholesterol Treatment Trialists' (CTT) Collaboration [94-96]. The observed overall $1.42 \mathrm{~kg}$ reduction in body weight may be considered clinically relevant [97] and may also play a role since obesity is a key risk factor for CVD [98]. Furthermore, a recent prospective cohort not captured in the systematic review and meta-analysis on the DASH dietary pattern and composite CVD outcomes, but which also supports the findings, showed an $11 \%$ reduced risk of all-cause mortality when comparing those participants who had the greatest improvement in DASH diet quality score over a 12-year follow-up period compared to those with a relatively stable diet quality [99]. Importantly, they also found a $9 \%$ reduced risk among those who maintained a high-quality DASH diet score over the 12-year period compared to those with consistently low diet scores over time [99]. These results highlight the CVD benefit of not only adopting or increasing adherence to a DASH dietary pattern, but also to maintaining a high compliance to it.

The observed reductions in diabetes incidence and improvements in glycemic control again may be attributable to the high consumption of fruit and vegetables as well as the low-fat dairy component of the DASH dietary pattern. Systematic reviews and meta-analyses have shown that fruit and vegetables alone or together [100] and low-fat milk and yogurt [101] are associated with reduced diabetes incidence. Again, dietary fibre coming from many of the foods may play a role since a recent systematic review and meta-analysis of prospective cohort studies found a $16 \%$ reduction in incidence of type 2 diabetes when comparing the highest to lowest fibre intakes ${ }^{84}$. The blood pressure lowering effects of the DASH diet may contribute to this effect since hypertension is associated with type 2 diabetes [102], where prospective cohort studies have demonstrated that a 1-mmHg increase in SBP is associated with a $1 \%-4 \%$ increase in type 2 diabetes risk $[103,104]$. The observed reduction in body weight may also contribute since body weight is strongly associated with diabetes risk [98]. The increase in legumes, nuts, fruit, whole grains and dietary fibre intake, especially from whole 
grain viscous fibres, as part of a DASH diet may also be the mechanism by which there is a reduction in $\mathrm{HbA} 1 \mathrm{c}$, since these have been demonstrated to improve glycemic control in systematic reviews and meta-analyses of randomized controlled trials [105-109] and have been associated with reduced diabetes incidence in systematic reviews and meta-analyses of prospective cohort studies $[110,111]$.

The DASH diet was originally developed to contain foods which increase magnesium, potassium, and calcium based on established links to lower blood pressure and successfully demonstrated a clinically meaningful blood pressure lowering effect [10]. Interactions between these nutrients can also have blood pressure lowering effects, such as the sodium-to-potassium ratio or the interaction between potassium and calcium and the ability to increase sodium excretion by the kidneys [112]. Potassium and calcium have previously been demonstrated to interact with the renin-angiotensin system by affecting plasma renin activity [113-115] and potassium can assist with sodium balances and has also been demonstrated to potentially lower blood pressure through endothelium-dependent vascular effects [115-117]. Additionally, it has been suggested that a reduction in blood pressure may result from an increased intake of nitrate-rich foods, including fruits and vegetables, especially leafy vegetables, via the role of inorganic nitrate in the non-enzymatic generation of nitric oxide [118]. Furthermore, many of the foods encouraged on the DASH diet have demonstrated blood pressure reductions in systematic reviews and meta-analyses of controlled trials in those with and without diabetes, including legumes [119], fruit [120], and whole grains, particularly those rich in viscous fibres $[106,121]$.

The observed reductions in lipids, including the primary lipid target for therapy, LDL-C, may be attributable to the high consumption of fruit, nuts, legumes, and whole grains (especially from oats and barley), increases in dietary fibre, and reductions in saturated fat intake as part of the DASH dietary pattern. Systematic reviews and meta-analyses of randomized controlled trials have shown that each of these alone [120,122-125] or combined as part of cholesterol-lowering dietary patterns such as the Portfolio dietary pattern [126] lowers Total-C and LDL-C.

The effect of the DASH dietary pattern on body weight may result from increased fruit and vegetable consumption, as was found in a systematic review and meta-analysis of randomized controlled trials [127]. Greater dietary fibre intake may contribute to weight loss since high-fibre foods require longer chewing time and promote gastric distention, triggering signals of fullness and slowed digestion, and delayed absorption of nutrients could delay hunger and subsequent energy intake [128]. Increasing dietary pulse intake has also been demonstrated in systematic reviews and meta-analyses of controlled trials to reduce body weight [129] and increase satiety [130]. Reduced sodium intake may also play a role in lowering body weight since high sodium intake is associated with obesity in the general population, possibly because of the associated increase in thirst and appetite [131].

Although a significant effect on CRP was not observed in the primary pooled analyses, subgroup analyses demonstrated that when the DASH diet was compared to an unhealthy or usual diet as opposed to a healthy diet (e.g. Portfolio diet) or when the follow up duration was $\geq 8$ weeks, the DASH diet resulted in a significantly lower CRP. If this is a true effect, then the reduction in inflammation may also play a key role in the observed reduction in incidence of cardiometabolic diseases. The effect may be mediated by increased dietary fibre intake [132] possibly because of the delay in glucose absorption and alteration to gut microflora which may suppress inflammatory cytokines production, stimulate the production of short-chain fatty acids and lead to lower circulating free fatty acid concentrations and, thus, subsequent inflammation [133-135]. The effect may also be the result of increased fruit and vegetable intake due to possible anti-inflammatory effects [136,137] and increased magnesium intake $[138,139]$. The high content of vitamin C, calcium and magnesium coming from fruits and vegetables in the DASH dietary pattern may reduce inflammation through reductions in oxidative stress via decreased NADPH oxidase activity [140] and by restoring the activity of anti-oxidative enzymes [141]. 


\subsection{Strengths and limitations}

The strengths of the current umbrella review include that the included systematic reviews and meta-analyses were all conducted recently with the census dates of each ranging from January 2012 to November 27, 2018 and an assessment of the overall certainty of the evidence was performed using the GRADE approach. The limitations include: indirectness for CHD incidence due to the inclusion of cohorts limited to middle-aged and elderly women and for $\mathrm{HbA} 1 \mathrm{c}$ due to the inclusion of 2 trials in either type 2 diabetes or gestational diabetes; unexplained inconsistency for diabetes incidence $\left(\mathrm{I}^{2}=62 \% ; P=0.03\right)$ and for $8 / 12$ risk factors; imprecision for $9 / 12$ risk factors; and publication bias for triglycerides. Although we did not downgrade the evidence for indirectness, concern may be raised that many of the included trials and cohorts were conducted in people without diabetes. We did not feel that there was any biological reason to believe that the DASH dietary pattern would behave differently in people with diabetes, as many components of the DASH dietary pattern have been shown individually to lower blood pressure and other established CVD risk factors in systematic reviews and meta-analyses of randomized controlled trials inclusive of people with diabetes without any evidence of a subgroup effect by diabetes status $[85,108,109,121,122,129,142,143]$. We also felt that this concern was mitigated by the evidence of similar or greater improvements in all of the measured outcomes (SBP, DBP, LDL-C, Total-C, HDL-C, TG, HbA1c, body weight, CRP) in those trials conducted exclusively in diabetes (that is, the effect estimates for these outcomes in the individual trials were contained within or exceeded the $95 \%$ confidence intervals of the overall pooled estimates).

Weighing the strengths and limitations, the certainty of the evidence based on the GRADE approach was rated as very low to low for associations with cardiometabolic disease incidence and low to moderate for effects on cardiometabolic risk factors.

\subsection{Implications}

Clinical practice guidelines recommend dietary strategies as the cornerstone of the prevention and management of CVD [4-9]. Our pooled analyses demonstrate that the DASH dietary pattern is associated with a $20 \%$ reduced CVD incidence and has blood pressure benefits which may translate to about a $20 \%$ reduction in risk of CVD, along with meaningful benefits in other established CVD risk factors in those with and without diabetes. In the systematic review and meta-analysis on the DASH dietary pattern and blood pressure, trials included participants who were hypertensive but not on medication $[10,49,53,56,58-60]$, as well as trials where participants were taking blood pressure medications [51,54], all of which found significant blood pressure lowering effects. Thus, the DASH dietary pattern may play a role both as a first line therapy as well as an add-on therapy.

There may be an important opportunity for people with and without diabetes to realize the CVD benefits of a DASH dietary pattern. The DASH dietary pattern emphasizes fruit, vegetables, low-fat dairy, whole grains, nuts and legumes, and limits total and saturated fat. Specifically, the DASH diet includes $4-5$ servings of fruits and vegetables per day, 2-3 servings of low fat dairy, 6-8 servings of whole grains and limits meat, poultry and fish to less than six servings per day. It also recommends 4-5 servings per week of nuts, seeds, dry beans, and peas and choosing foods with low saturated fat, high potassium and fibre, and low sodium. Dietary intake patterns in Europe and other Western countries do not currently meet these targets. The European Health Interview Survey (EHIS) (Eurostat 2016) reports that, on average, more than a third of the EU adults do not consume any fruits and vegetables on a daily basis and only $14.1 \%$ consume five portions per day [144]; about one third of those aged 35 and older had average intakes of saturated fat $\geq 15 \mathrm{E} \%$ [145]; although a high total consumption of dairy products was reported in the Dutch, Swedish and Danish, and most of Spain and the UK, a somewhat low consumption was reported Greece and in some of Italy (Ragusa and Turin) [146]. According to the most recent survey in the United States, only one in 10 adults and youths eat the recommended amount of fruits or vegetables [147], only 1.9 servings/day of dairy products are consumed on average [148], only $\sim 38.2 \%$ of adults consume nuts on a given day [149] and most exceed the recommendations for added sugars, saturated fats, and sodium [14]. These data suggest 
that in these populations that there is an opportunity for people with and without diabetes to increase these foods to achieve a DASH dietary pattern and realize the cardiometabolic benefits.

\section{Conclusions}

In conclusion, this synthesis of systematic reviews and meta-analyses demonstrates that the DASH dietary pattern as a well-accepted blood pressure-lowering diet has associated CVD benefit supported by reductions in blood pressure, $\mathrm{HbA1c}$, LDL-C and other established CVD risk factors in people with and without diabetes. The certainty of the evidence based on the GRADE approach was very low to low for associations with cardiometabolic disease incidence and low to moderate for effects on cardiometabolic risk factors. More research is needed to improve the estimates and confirm that these benefits do translate into reductions in clinical outcomes of clinical practice and public health importance. In this regard, there remains a need for large randomized trials of the effect of the DASH dietary pattern on clinical CVD outcomes in those with and without diabetes. The available evidence does support a potential opportunity for those with and without diabetes to adopt the DASH dietary pattern to improve cardiometabolic health.

Supplementary Materials: The following are available online at http:/ /www.mdpi.com/2072-6643/11/2/338/s1. Table S1. Search strategy for the identification of systematic reviews and meta-analyses assessing the relationships of the DASH dietary pattern with incident cardiometabolic diseases and on cardiometabolic risk factors. Table S2. Characteristics of prospective cohort studies investigating the DASH dietary pattern and CVD incidence. Table S3. Analysis of confounding variables among studies of the DASH dietary pattern and CVD incidence. Table S4. Newcastle-Ottawa Scale (NOS) for assessing the quality of cohort studies for studies of the DASH diet and CVD incidence. Table S5. GRADE assessments of systematic reviews and meta-analyses of prospective cohort studies assessing the relationship between consumption of the DASH dietary pattern and cardiometabolic disease incidence. Table S6. Characteristics of prospective cohort studies investigating the DASH dietary pattern and incidence of CHD. Table S7. Analysis of confounding variables among studies of the DASH dietary pattern and incidence of CHD. Table S8. Newcastle-Ottawa Scale (NOS) for assessing the quality of cohort studies for studies of the DASH diet and incidence of CHD. Table S9. Characteristics of prospective cohort studies investigating the DASH dietary pattern and incidence of stroke. Table S10. Analysis of confounding variables among studies of the DASH dietary pattern and incidence of stroke. Table S11. Newcastle-Ottawa Scale (NOS) for assessing the quality of cohort studies for studies of the DASH diet and incidence of stroke. Table S12. Characteristics of prospective cohort studies investigating the DASH dietary pattern and incidence of diabetes. Table S13. Analysis of confounding variables among studies of the DASH dietary pattern and incidence of diabetes. Table S14. Newcastle-Ottawa Scale (NOS) for assessing the quality of cohort studies for studies of the DASH diet and incidence of diabetes. Table S15. Characteristics of controlled trials investigating the DASH dietary pattern and blood pressure. Table S16. GRADE assessment of the systematic review and meta-analysis of controlled trials assessing the effect of the DASH dietary pattern on cardiometabolic risk factors. Table S17. Characteristics of controlled trials investigating the DASH dietary pattern and Total-C and LDL-C. Table S18. Characteristics of controlled trials investigating the DASH dietary pattern and HDL-C. Table S19. Characteristics of controlled trials investigating the DASH dietary pattern and triglycerides. Table S20. Search strategy for controlled clinical trials assessing the effect of the DASH diet intervention on HbA1c. Table S21. Characteristics of controlled trials investigating the DASH dietary pattern and $\mathrm{HbA1c}$. Table S22. Characteristics of controlled trials investigating the DASH dietary pattern and blood glucose. Table S23. Characteristics of controlled trials investigating the DASH dietary pattern and fasting insulin. Table S24. Characteristics of controlled trials investigating the DASH dietary pattern and HOMA-IR. Table S25. Characteristics of controlled trials investigating the DASH dietary pattern and body weight. Table S26. Characteristics of controlled trials investigating the DASH dietary pattern and CRP. Figure S1. Risk of Bias summary for all controlled trials included in the systematic reviews and meta-analyses of cardiovascular risk factors. Figure S2. Risk of Bias graph for all controlled trials included in the systematic reviews and meta-analyses of cardiovascular risk factors. Figure S3. Literature search for the effect of the DASH diet intervention on $\mathrm{HbA1}$ c in controlled clinical trials. Figure S4. Forest plot for controlled trials investigating the effect of the DASH dietary pattern on HbA1c.

Author Contributions: L.C., E.V., S.K.N., and J.L.S. had full access to all of the data in the study and take responsibility for the integrity of the data and the accuracy of the data analysis. L.C., S.B.M., D.R., H.K., J.S.S., C.W.C.K., and J.L.S. were responsible for the study concept and design. L.C., E.V., S.K.N., S.B.M., D.R., H.K., J.S.S., C.W.C.K., and J.L.S. were responsible for the acquisition, analysis, and interpretation of data. L.C. drafted the manuscript. All the authors contributed to the critical revision of the manuscript for important intellectual content. L.C., E.V., and S.K.N. conducted the statistical analysis. J.L.S. supervised the study. J.L.S. was the study guarantor. The corresponding author attests that all listed authors meet authorship criteria and that no others meeting the criteria have been omitted.

Funding: The Diabetes and Nutrition Study Group (DNSG) of the European Association for the Study of Diabetes (EASD) commissioned this systematic review and meta-analysis and provided funding and logistical support for 
meetings as part of the development of the EASD Clinical Practice Guidelines for Nutrition Therapy. This work was also supported by the Canadian Institutes of Health Research (funding reference number, 129920) through the Canada-wide Human Nutrition Trialists' Network (NTN). The Diet, Digestive tract, and Disease (3-D) Centre, funded through the Canada Foundation for Innovation (CFI) and the Ministry of Research and Innovation's Ontario Research Fund (ORF), provided the infrastructure for the conduct of this project. Laura Chiavaroli was funded by a Toronto 3D Knowledge Synthesis and Clinical Trials foundation Postdoctoral Fellowship Award. Effie Viguiliouk was supported by a Toronto 3D Knowledge Synthesis and Clinical Trials foundation Internship Award. John L Sievenpiper was funded by a PSI Graham Farquharson Knowledge Translation Fellowship, Diabetes Canada Clinician Scientist award, CIHR INMD/CNS New Investigator Partnership Prize, and Banting and Best Diabetes Centre Sun Life Financial New Investigator Award. With the exception of the Clinical Practice Guidelines Committee of the DNSG of the EASD, none of the sponsors had a role in any aspect of the present study, including design and conduct of the study; collection, management, analysis, and interpretation of the data; and preparation, review, approval of the manuscript or decision to publish.

Conflicts of Interest: D.R. has served as principal investigator or co-investigator in clinical trials of AstraZeneca, Eli Lilly, MSD, Novo Nordisk, Sanofi Aventis, Solvay and Trophos. He received honoraria for speaking or advisory board engagements and consulting fees from Abbott, Amgen, AstraZeneca, Bayer, Boehringer Ingelheim, Eli Lilly, Lifescan-Johnson and Johnson, Novartis, Novo Nordisk, MSD, Merck Sharp and Dohme, Pfizer, Pliva, Roche, Salvus, Sanofi Aventis and Takeda. He served as a Board member and Secretary of IDF Europe in biennium 2015-2017. He is a president of Croatian Society for Diabetes and Metabolic Disorders of Croatian Medical Association, chair of IDF Young Leaders in Diabetes Programme, Executive committee member of Diabetes and Cardiovascular Disease Study Group of EASD, Croatian Endocrine Society, Croatian Society for Obesity and Croatian Society for Endocrine Oncology. J.S.S. reports serving on the board of and receiving grant support through his institution from the International Nut and Dried Fruit Council, and Eroski Foundation and serving on the Executive Committee of the Instituto Danone Spain and on the Scientific Committee of the Danone International Institute. Has received research support from the Instituto de Salud Carlos III, Spain; Ministerio de Educación y Ciencia, Spain; Departament de Salut Pública de la Generalitat de Catalunya, Catalonia, Spain; European Commission. He has received research support from California Walnut Commission, Sacramento CA, USA; Patrimonio Comunal Olivarero, Spain; La Morella Nuts, Spain; and Borges S.A., Spain. Reports receiving consulting fees or travel expenses from Danone; California Walnut Commission, Eroski Foundation, Instituto Danone-Spain, Nuts for Life, Australian Nut Industry Council, Nestlé, Abbot Laboratories, and Font Vella Lanjarón. He is on the Clinical Practice Guidelines Expert Committee of the European Association for the study of Diabetes (EASD), and served in the Scientific Committee of the Spanish Food and Safety Agency, and the Spanish Federation of the Scientific Societies of Food, Nutrition and Dietetics. He is a member of the International Carbohydrate Quality Consortium (ICQC), and Executive Board Member of the Diabetes and Nutrition Study Group (DNSG) of the EASD. C.W.C.K. has received grant grants or research support from the Advanced Food Materials Network, Agriculture and Agri-Foods Canada (AAFC), Almond Board of California, American Pistachio Growers, Barilla, California Strawberry Commission, Calorie Control Council, Canadian Institutes of Health Research (CIHR), Canola Council of Canada, International Nut and Dried Fruit Council, International Tree Nut Council Research and Education Foundation, Loblaw Brands Ltd., Pulse Canada, Saskatchewan Pulse Growers and Unilever. He has received in-kind research support from the Almond Board of California, California Walnut Council, American Peanut Council, Barilla, Unilever, Unico/Primo, Loblaw Companies, Quaker (Pepsico), Pristine Gourmet, Kellogg Canada, WhiteWave Foods. He has received travel support and/or honoraria from the American Peanut Council, American Pistachio Growers, Barilla, Bayer, California Walnut Commission, Canola Council of Canada, General Mills, International Tree Nut Council, Loblaw Brands Ltd., Nutrition Foundation of Italy, Oldways Preservation Trust, Orafti, Paramount Farms, Peanut Institute, Pulse Canada, Sabra Dipping Co., Saskatchewan Pulse Growers, Sun-Maid, Tate and Lyle, Unilever and White Wave Foods. He has served on the scientific advisory board for the International Tree Nut Council, McCormick Science Institute, Oldways Preservation Trust, Paramount Farms and Pulse Canada. He is a member of the International Carbohydrate Quality Consortium (ICQC), Executive Board Member of the Diabetes and Nutrition Study Group (DNSG) of the European Association for the Study of Diabetes (EASD), is on the Clinical Practice Guidelines Expert Committee for Nutrition Therapy of the EASD and is a Director of the Toronto 3D Knowledge Synthesis and Clinical Trials foundation. J.L.S. has received research support from the Canadian Institutes of health Research (CIHR), Diabetes Canada, PSI Foundation, Banting and Best Diabetes Centre (BBDC), Canadian Nutrition Society (CNS), American Society for Nutrition (ASN), INC International Nut and Dried Fruit Council Foundation, National Dried Fruit Trade Association, The Tate and Lyle Nutritional Research Fund at the University of Toronto, The Glycemic Control and Cardiovascular Disease in Type 2 Diabetes Fund at the University of Toronto (a fund established by the Alberta Pulse Growers) and the Nutrition Trialists Fund at the University of Toronto (a fund established by the Calorie Control Council). He has received in-kind research support from the Almond Board of California, California Walnut Commission, American Peanut Council, Barilla, Unilever, Unico/Primo, Loblaw Companies, Quaker (Pepsico), Kellogg Canada, WhiteWave Foods. He has received travel support, speaker fees and/or honoraria from Diabetes Canada, Canadian Nutrition Society (CNS), Mott's LLP, Dairy Farmers of Canada, FoodMinds LLC, Memac Ogilvy \& Mather LLC, PepsiCo, The Ginger Network LLC, International Sweeteners Association, Nestlé, Pulse Canada, Canadian Society for Endocrinology and Metabolism (CSEM), GI Foundation, Abbott, Biofortis, American Society for Nutrition (ASN), and Physicians Committee for Responsible Medicine. He has ad hoc consulting arrangements with Perkins Coie LLP, Tate and Lyle, and Wirtschaftliche Vereinigung Zucker e.V. He is a member of the European Fruit Juice Association Scientific Expert Panel. He is on the Clinical Practice 
Guidelines Expert Committees of Diabetes Canada, European Association for the study of Diabetes (EASD), Canadian Cardiovascular Society (CCS), and Obesity Canada. He serves as an unpaid scientific advisor for the Food, Nutrition, and Safety Program (FNSP) and the Technical Committee on Carbohydrates of the International Life Science Institute (ILSI) North America. He is a member of the International Carbohydrate Quality Consortium (ICQC), Executive Board Member of the Diabetes and Nutrition Study Group (DNSG) of the EASD, and Director of the Toronto 3D Knowledge Synthesis and Clinical Trials foundation. No competing interests were declared by L.C., E.V., S.K.N., S.B.M., and H.K.

\section{References}

1. International Diabetes Federation. IDF Diabetes Atlas, 7th ed. 2015. Available online: http://www. diabetesatlas.org/resources/2015-atlas.html (accessed on 30 January 2018).

2. O'Rourke, K.; VanderZanden, A.; Shepard, D.; Leach-Kemon, K. Cardiovascular disease worldwide, 1990-2013. JAMA 2015, 314, 1905. [CrossRef]

3. World Health Organization (WHO). Obesity. Available online: http://www.who.int/gho/ncd/riskfactors/ obesity_text/en/ (accessed on 30 January 2018).

4. Chobanian, A.V.; Bakris, G.L.; Black, H.R.; Cushman, W.C.; Green, L.A.; Izzo, J.L., Jr.; Jones, D.W.; Materson, B.J.; Oparil, S.; Wright, J.T., Jr.; et al. The Seventh Report of the Joint National Committee on Prevention, Detection, Evaluation, and Treatment of High Blood Pressure: The JNC 7 report. JAMA 2003, 289, 2560-2572. [CrossRef]

5. American Heart Association Nutrition Committee; Lichtenstein, A.H.; Appel, L.J.; Brands, M.; Carnethon, M.; Daniels, S.; Franch, H.A.; Franklin, B.; Kris-Etherton, P.; Harris, W.S.; et al. Diet and lifestyle recommendations revision 2006: A scientific statement from the American Heart Association Nutrition Committee. Circulation 2006, 114, 82-96. [CrossRef] [PubMed]

6. Anderson, T.J.; Gregoire, J.; Pearson, G.J.; Barry, A.R.; Couture, P.; Dawes, M.; Francis, G.A.; Genest, J., Jr.; Grover, S.; Gupta, M.; et al. 2016 Canadian Cardiovascular Society Guidelines for the Management of Dyslipidemia for the Prevention of Cardiovascular Disease in the Adult. Can. J. Cardiol. 2016, 32, 1263-1282. [CrossRef]

7. Evert, A.B.; Boucher, J.L.; Cypress, M.; Dunbar, S.A.; Franz, M.J.; Mayer-Davis, E.J.; Neumiller, J.J.; Nwankwo, R.; Verdi, C.L.; Urbanski, P.; et al. Nutrition therapy recommendations for the management of adults with diabetes. Diabetes Care 2014, 37 (Suppl. 1), S120-S143. [CrossRef]

8. Canadian Diabetes Association Clinical Practice Guidelines Expert Committee; Dworatzek, P.D.; Arcudi, K.; Gougeon, R.; Husein, N.; Sievenpiper, J.L.; Williams, S.L. Nutrition therapy. Can. J. Diabetes 2013, 37 (Suppl. 1), S45-S55. [CrossRef] [PubMed]

9. Nerenberg, K.A.; Zarnke, K.B.; Leung, A.A.; Dasgupta, K.; Butalia, S.; McBrien, K.; Harris, K.C.; Nakhla, M.; Cloutier, L.; Gelfer, M.; et al. Hypertension Canada's 2018 Guidelines for Diagnosis, Risk Assessment, Prevention, and Treatment of Hypertension in Adults and Children. Can. J. Cardiol. 2018, 34, 506-525. [CrossRef]

10. Sacks, F.M.; Svetkey, L.P.; Vollmer, W.M.; Appel, L.J.; Bray, G.A.; Harsha, D.; Obarzanek, E.; Conlin, P.R.; Miller, E.R., 3rd; Simons-Morton, D.G.; et al. Effects on blood pressure of reduced dietary sodium and the Dietary Approaches to Stop Hypertension (DASH) diet. DASH-Sodium Collaborative Research Group. N. Engl. J. Med. 2001, 344, 3-10. [CrossRef] [PubMed]

11. Siervo, M.; Lara, J.; Chowdhury, S.; Ashor, A.; Oggioni, C.; Mathers, J.C. Effects of the Dietary Approach to Stop Hypertension (DASH) diet on cardiovascular risk factors: A systematic review and meta-analysis. Br. J. Nutr. 2015, 113, 1-15. [CrossRef] [PubMed]

12. Jannasch, F.; Kroger, J.; Schulze, M.B. Dietary Patterns and Type 2 Diabetes: A Systematic Literature Review and Meta-Analysis of Prospective Studies. J. Nutr. 2017, 147, 1174-1182. [CrossRef]

13. Schwingshackl, L.; Hoffmann, G. Diet quality as assessed by the Healthy Eating Index, the Alternate Healthy Eating Index, the Dietary Approaches to Stop Hypertension score, and health outcomes: A systematic review and meta-analysis of cohort studies. J. Acad. Nutr. Diet. 2015, 115, 780-800 e785. [CrossRef] [PubMed]

14. U.S. Department of Health and Human Services and U.S. Department of Agriculture. 2015-2020 Dietary Guidelines for Americans, 8th ed.; December 2015. Available online: http:/ / health.gov/dietaryguidelines / 2015/guidelines/ (accessed on 27 November 2018). 
15. Diabetes Canada Clinical Practice Guidelines Expert Committee; Sievenpiper, J.L.; Chan, C.B.; Dworatzek, P.D.; Freeze, C.; Williams, S.L. Nutrition Therapy. Can. J. Diabetes 2018, 42 (Suppl. 1), S64-S79. [CrossRef] [PubMed]

16. Piepoli, M.F.; Hoes, A.W.; Agewall, S.; Albus, C.; Brotons, C.; Catapano, A.L.; Cooney, M.T.; Corra, U.; Cosyns, B.; Deaton, C.; et al. 2016 European Guidelines on cardiovascular disease prevention in clinical practice: The Sixth Joint Task Force of the European Society of Cardiology and Other Societies on Cardiovascular Disease Prevention in Clinical Practice (constituted by representatives of 10 societies and by invited experts)Developed with the special contribution of the European Association for Cardiovascular Prevention \& Rehabilitation (EACPR). Eur. Heart J. 2016, 37, 2315-2381. [PubMed]

17. Eckel, R.H.; Jakicic, J.M.; Ard, J.D.; de Jesus, J.M.; Houston Miller, N.; Hubbard, V.S.; Lee, I.M.; Lichtenstein, A.H.; Loria, C.M.; Millen, B.E.; et al. 2013 AHA/ACC guideline on lifestyle management to reduce cardiovascular risk: A report of the American College of Cardiology/American Heart Association Task Force on Practice Guidelines. J. Am. Coll. Cardiol. 2014, 63, 2960-2984. [CrossRef] [PubMed]

18. Higgins, J.P.T.; Green, S. Cochrane Handbook for Systematic Reviews of Interventions version 5.1.0 [updated March 2011]. Cochrane Collaboration. Available online: https://handbook-5-1.cochrane.org/ (accessed on 27 November 2018).

19. Guyatt, G.; Oxman, A.D.; Akl, E.A.; Kunz, R.; Vist, G.; Brozek, J.; Norris, S.; Falck-Ytter, Y.; Glasziou, P.; DeBeer, H.; et al. GRADE guidelines: 1. Introduction-GRADE evidence profiles and summary of findings tables. J. Clin. Epidemiol. 2011, 64, 383-394. [CrossRef]

20. Moher, D.; Liberati, A.; Tetzlaff, J.; Altman, D.G.; Group, P. Preferred reporting items for systematic reviews and meta-analyses: The PRISMA statement. Int. J. Surg. 2010, 8, 336-341. [CrossRef] [PubMed]

21. Wells, G.A.; Shea, B.; O'Connell, D.; Peterson, J.; Welch, V.; Losos, M.; Tugwell, P. The Newcastle-Ottawa Scale (NOS) for Assessing the Quality of Nonrandomised Studies in Meta-Analyses; Ottawa Hospital Research Institute: Ottawa, Canada, 2014; Available online: www.ohri.ca/programs/clinical_epidemiology/oxford. asp (accessed on 30 January 2018).

22. Higgins, J.P.; Altman, D.G.; Gotzsche, P.C.; Juni, P.; Moher, D.; Oxman, A.D.; Savovic, J.; Schulz, K.F.; Weeks, L.; Sterne, J.A.; et al. The Cochrane Collaboration's tool for assessing risk of bias in randomised trials. BMJ 2011, 343, d5928. [CrossRef]

23. Balshem, H.; Helfand, M.; Schunemann, H.J.; Oxman, A.D.; Kunz, R.; Brozek, J.; Vist, G.E.; Falck-Ytter, Y.; Meerpohl, J.; Norris, S.; et al. GRADE guidelines: 3. Rating the quality of evidence. J. Clin. Epidemiol. 2011, 64, 401-406. [CrossRef]

24. Brunetti, M.; Shemilt, I.; Pregno, S.; Vale, L.; Oxman, A.D.; Lord, J.; Sisk, J.; Ruiz, F.; Hill, S.; Guyatt, G.H.; et al. GRADE guidelines: 10. Considering resource use and rating the quality of economic evidence. J. Clin. Epidemiol. 2013, 66, 140-150. [CrossRef]

25. Guyatt, G.; Oxman, A.D.; Sultan, S.; Brozek, J.; Glasziou, P.; Alonso-Coello, P.; Atkins, D.; Kunz, R.; Montori, V.; Jaeschke, R.; et al. GRADE guidelines: 11. Making an overall rating of confidence in effect estimates for a single outcome and for all outcomes. J. Clin. Epidemiol. 2013, 66, 151-157. [CrossRef]

26. Guyatt, G.H.; Oxman, A.D.; Kunz, R.; Atkins, D.; Brozek, J.; Vist, G.; Alderson, P.; Glasziou, P.; Falck-Ytter, Y.; Schunemann, H.J. GRADE guidelines: 2. Framing the question and deciding on important outcomes. J. Clin. Epidemiol. 2011, 64, 395-400. [CrossRef] [PubMed]

27. Guyatt, G.H.; Oxman, A.D.; Kunz, R.; Brozek, J.; Alonso-Coello, P.; Rind, D.; Devereaux, P.J.; Montori, V.M.; Freyschuss, B.; Vist, G.; et al. GRADE guidelines 6. Rating the quality of evidence-imprecision. J. Clin. Epidemiol. 2011, 64, 1283-1293. [CrossRef] [PubMed]

28. Guyatt, G.H.; Oxman, A.D.; Kunz, R.; Woodcock, J.; Brozek, J.; Helfand, M.; Alonso-Coello, P.; Falck-Ytter, Y.; Jaeschke, R.; Vist, G.; et al. GRADE guidelines: 8. Rating the quality of evidence-indirectness. J. Clin. Epidemiol. 2011, 64, 1303-1310. [CrossRef] [PubMed]

29. Guyatt, G.H.; Oxman, A.D.; Kunz, R.; Woodcock, J.; Brozek, J.; Helfand, M.; Alonso-Coello, P.; Glasziou, P.; Jaeschke, R.; Akl, E.A.; et al. GRADE guidelines: 7. Rating the quality of evidence-inconsistency. J. Clin. Epidemiol. 2011, 64, 1294-1302. [CrossRef] [PubMed]

30. Guyatt, G.H.; Oxman, A.D.; Montori, V.; Vist, G.; Kunz, R.; Brozek, J.; Alonso-Coello, P.; Djulbegovic, B.; Atkins, D.; Falck-Ytter, Y.; et al. GRADE guidelines: 5. Rating the quality of evidence-Publication bias. J. Clin. Epidemiol. 2011, 64, 1277-1282. [CrossRef] [PubMed] 
31. Guyatt, G.H.; Oxman, A.D.; Santesso, N.; Helfand, M.; Vist, G.; Kunz, R.; Brozek, J.; Norris, S.; Meerpohl, J.; Djulbegovic, B.; et al. GRADE guidelines: 12. Preparing summary of findings tables-binary outcomes. J. Clin. Epidemiol. 2013, 66, 158-172. [CrossRef] [PubMed]

32. Guyatt, G.H.; Oxman, A.D.; Sultan, S.; Glasziou, P.; Akl, E.A.; Alonso-Coello, P.; Atkins, D.; Kunz, R.; Brozek, J.; Montori, V.; et al. GRADE guidelines: 9. Rating up the quality of evidence. J. Clin. Epidemiol. 2011, 64, 1311-1316. [CrossRef]

33. Guyatt, G.H.; Oxman, A.D.; Vist, G.; Kunz, R.; Brozek, J.; Alonso-Coello, P.; Montori, V.; Akl, E.A.; Djulbegovic, B.; Falck-Ytter, Y.; et al. GRADE guidelines: 4. Rating the quality of evidence-Study limitations (risk of bias). J. Clin. Epidemiol. 2011, 64, 407-415. [CrossRef]

34. Guyatt, G.H.; Thorlund, K.; Oxman, A.D.; Walter, S.D.; Patrick, D.; Furukawa, T.A.; Johnston, B.C.; Karanicolas, P.; Akl, E.A.; Vist, G.; et al. GRADE guidelines: 13. Preparing summary of findings tables and evidence profiles-continuous outcomes. J. Clin. Epidemiol. 2013, 66, 173-183. [CrossRef]

35. Agnoli, C.; Krogh, V.; Grioni, S.; Sieri, S.; Palli, D.; Masala, G.; Sacerdote, C.; Vineis, P.; Tumino, R.; Frasca, G.; et al. A priori-defined dietary patterns are associated with reduced risk of stroke in a large Italian cohort. J. Nutr. 2011, 141, 1552-1558. [CrossRef]

36. Bertoia, M.L.; Triche, E.W.; Michaud, D.S.; Baylin, A.; Hogan, J.W.; Neuhouser, M.L.; Tinker, L.F.; Van Horn, L.; Waring, M.E.; Li, W.; et al. Mediterranean and Dietary Approaches to Stop Hypertension dietary patterns and risk of sudden cardiac death in postmenopausal women. Am. J. Clin. Nutr. 2014, 99, 344-351. [CrossRef] [PubMed]

37. Fitzgerald, K.C.; Chiuve, S.E.; Buring, J.E.; Ridker, P.M.; Glynn, R.J. Comparison of associations of adherence to a Dietary Approaches to Stop Hypertension (DASH)-style diet with risks of cardiovascular disease and venous thromboembolism. J. Thromb. Haemost. 2012, 10, 189-198. [CrossRef] [PubMed]

38. Folsom, A.R.; Parker, E.D.; Harnack, L.J. Degree of concordance with DASH diet guidelines and incidence of hypertension and fatal cardiovascular disease. Am. J. Hypertens. 2007, 20, 225-232. [CrossRef] [PubMed]

39. Fung, T.T.; Chiuve, S.E.; McCullough, M.L.; Rexrode, K.M.; Logroscino, G.; Hu, F.B. Adherence to a DASH-style diet and risk of coronary heart disease and stroke in women. Arch. Intern. Med. 2008, 168, 713-720. [CrossRef] [PubMed]

40. Levitan, E.B.; Wolk, A.; Mittleman, M.A. Consistency with the DASH diet and incidence of heart failure. Arch. Intern. Med. 2009, 169, 851-857. [CrossRef] [PubMed]

41. Lin, P.H.; Yeh, W.T.; Svetkey, L.P.; Chuang, S.Y.; Chang, Y.C.; Wang, C.; Pan, W.H. Dietary intakes consistent with the DASH dietary pattern reduce blood pressure increase with age and risk for stroke in a Chinese population. Asia Pac. J. Clin. Nutr. 2013, 22, 482-491. [PubMed]

42. Reedy, J.; Krebs-Smith, S.M.; Miller, P.E.; Liese, A.D.; Kahle, L.L.; Park, Y.; Subar, A.F. Higher diet quality is associated with decreased risk of all-cause, cardiovascular disease, and cancer mortality among older adults. J. Nutr. 2014, 144, 881-889. [CrossRef]

43. Salehi-Abargouei, A.; Maghsoudi, Z.; Shirani, F.; Azadbakht, L. Effects of Dietary Approaches to Stop Hypertension (DASH)-style diet on fatal or nonfatal cardiovascular diseases-incidence: A systematic review and meta-analysis on observational prospective studies. Nutrition 2013, 29, 611-618. [CrossRef]

44. de Koning, L.; Chiuve, S.E.; Fung, T.T.; Willett, W.C.; Rimm, E.B.; Hu, F.B. Diet-quality scores and the risk of type 2 diabetes in men. Diabetes Care 2011, 34, 1150-1156. [CrossRef]

45. Otto, M.C.; Padhye, N.S.; Bertoni, A.G.; Jacobs, D.R., Jr.; Mozaffarian, D. Everything in Moderation-Dietary Diversity and Quality, Central Obesity and Risk of Diabetes. PLoS ONE 2015, 10, e0141341.

46. Jacobs, S.; Harmon, B.E.; Boushey, C.J.; Morimoto, Y.; Wilkens, L.R.; Le Marchand, L.; Kroger, J.; Schulze, M.B.; Kolonel, L.N.; Maskarinec, G. A priori-defined diet quality indexes and risk of type 2 diabetes: The Multiethnic Cohort. Diabetologia 2015, 58, 98-112. [CrossRef] [PubMed]

47. InterAct, $\mathrm{C}$. Adherence to predefined dietary patterns and incident type 2 diabetes in European populations: EPIC-InterAct Study. Diabetologia 2014, 57, 321-333.

48. Liese, A.D.; Nichols, M.; Sun, X.; D'Agostino, R.B., Jr.; Haffner, S.M. Adherence to the DASH Diet is inversely associated with incidence of type 2 diabetes: The insulin resistance atherosclerosis study. Diabetes Care 2009, 32, 1434-1436. [CrossRef] [PubMed]

49. Appel, L.J.; Moore, T.J.; Obarzanek, E.; Vollmer, W.M.; Svetkey, L.P.; Sacks, F.M.; Bray, G.A.; Vogt, T.M.; Cutler, J.A.; Windhauser, M.M.; et al. A clinical trial of the effects of dietary patterns on blood pressure. DASH Collaborative Research Group. N. Engl. J. Med. 1997, 336, 1117-1124. [CrossRef] [PubMed] 
50. Appel, L.J.; Champagne, C.M.; Harsha, D.W.; Cooper, L.S.; Obarzanek, E.; Elmer, P.J.; Stevens, V.J.; Vollmer, W.M.; Lin, P.H.; Svetkey, L.P.; et al. Effects of comprehensive lifestyle modification on blood pressure control: Main results of the PREMIER clinical trial. JAMA 2003, 289, 2083-2093. [PubMed]

51. Conlin, P.R.; Erlinger, T.P.; Bohannon, A.; Miller, E.R., 3rd; Appel, L.J.; Svetkey, L.P.; Moore, T.J. The DASH diet enhances the blood pressure response to losartan in hypertensive patients. Am. J. Hypertens. 2003, 16, 337-342. [CrossRef]

52. Lopes, H.F.; Martin, K.L.; Nashar, K.; Morrow, J.D.; Goodfriend, T.L.; Egan, B.M. DASH diet lowers blood pressure and lipid-induced oxidative stress in obesity. Hypertension 2003, 41, 422-430. [CrossRef] [PubMed]

53. Nowson, C.A.; Wattanapenpaiboon, N.; Pachett, A. Low-sodium Dietary Approaches to Stop Hypertension-type diet including lean red meat lowers blood pressure in postmenopausal women. Nutr. Res. 2009, 29, 8-18. [CrossRef]

54. Nowson, C.A.; Worsley, A.; Margerison, C.; Jorna, M.K.; Frame, A.G.; Torres, S.J.; Godfrey, S.J. Blood pressure response to dietary modifications in free-living individuals. J. Nutr. 2004, 134, 2322-2329. [CrossRef]

55. Nowson, C.A.; Worsley, A.; Margerison, C.; Jorna, M.K.; Godfrey, S.J.; Booth, A. Blood pressure change with weight loss is affected by diet type in men. Am. J. Clin. Nutr. 2005, 81, 983-989. [CrossRef]

56. Azadbakht, L.; Mirmiran, P.; Esmaillzadeh, A.; Azizi, T.; Azizi, F. Beneficial effects of a Dietary Approaches to Stop Hypertension eating plan on features of the metabolic syndrome. Diabetes Care 2005, 28, 2823-2831. [CrossRef] [PubMed]

57. Azadbakht, L.; Surkan, P.J.; Esmaillzadeh, A.; Willett, W.C. The Dietary Approaches to Stop Hypertension eating plan affects $C$-reactive protein, coagulation abnormalities, and hepatic function tests among type 2 diabetic patients. J. Nutr. 2011, 141, 1083-1088. [CrossRef] [PubMed]

58. Al-Solaiman, Y.; Jesri, A.; Mountford, W.K.; Lackland, D.T.; Zhao, Y.; Egan, B.M. DASH lowers blood pressure in obese hypertensives beyond potassium, magnesium and fibre. J. Hum. Hypertens. 2010, 24, 237-246. [CrossRef] [PubMed]

59. Blumenthal, J.A.; Babyak, M.A.; Hinderliter, A.; Watkins, L.L.; Craighead, L.; Lin, P.H.; Caccia, C.; Johnson, J.; Waugh, R.; Sherwood, A. Effects of the DASH diet alone and in combination with exercise and weight loss on blood pressure and cardiovascular biomarkers in men and women with high blood pressure: The ENCORE study. Arch. Intern. Med. 2010, 170, 126-135. [CrossRef] [PubMed]

60. Malloy-McFall, J.; Barkley, J.E.; Gordon, K.L.; Burzminski, N.; Glickman, E.L. Effect of the DASH Diet on Preand Stage 1 Hypertensive Individuals in a Free-Living Environment. Nutr. Metab. Insights 2010, 3, 15-23. [CrossRef] [PubMed]

61. Edwards, K.M.; Wilson, K.L.; Sadja, J.; Ziegler, M.G.; Mills, P.J. Effects on blood pressure and autonomic nervous system function of a 12-week exercise or exercise plus DASH-diet intervention in individuals with elevated blood pressure. Acta Physiol. (Oxf.) 2011, 203, 343-350. [CrossRef] [PubMed]

62. Lin, P.H.; Allen, J.D.; Li, Y.J.; Yu, M.; Lien, L.F.; Svetkey, L.P. Blood Pressure-Lowering Mechanisms of the DASH Dietary Pattern. J. Nutr. Metab. 2012, 2012, 472396. [CrossRef]

63. Asemi, Z.; Tabassi, Z.; Samimi, M.; Fahiminejad, T.; Esmaillzadeh, A. Favourable effects of the Dietary Approaches to Stop Hypertension diet on glucose tolerance and lipid profiles in gestational diabetes: A randomised clinical trial. Br. J. Nutr. 2013, 109, 2024-2030. [CrossRef]

64. Shirani, F.; Salehi-Abargouei, A.; Azadbakht, L. Effects of Dietary Approaches to Stop Hypertension (DASH) diet on some risk for developing type 2 diabetes: A systematic review and meta-analysis on controlled clinical trials. Nutrition 2013, 29, 939-947. [CrossRef]

65. Soltani, S.; Shirani, F.; Chitsazi, M.J.; Salehi-Abargouei, A. The effect of dietary approaches to stop hypertension (DASH) diet on weight and body composition in adults: A systematic review and meta-analysis of randomized controlled clinical trials. Obes. Rev. 2016, 17, 442-454. [CrossRef]

66. Soltani, S.; Chitsazi, M.J.; Salehi-Abargouei, A. The effect of dietary approaches to stop hypertension (DASH) on serum inflammatory markers: A systematic review and meta-analysis of randomized trials. Clin. Nutr. 2018, 37, 542-550. [CrossRef] [PubMed]

67. Harsha, D.W.; Sacks, F.M.; Obarzanek, E.; Svetkey, L.P.; Lin, P.H.; Bray, G.A.; Aickin, M.; Conlin, P.R.; Miller, E.R., 3rd; Appel, L.J. Effect of dietary sodium intake on blood lipids: Results from the DASH-sodium trial. Hypertension 2004, 43, 393-398. [CrossRef] [PubMed] 
68. Chen, S.T.; Maruthur, N.M.; Appel, L.J. The effect of dietary patterns on estimated coronary heart disease risk: Results from the Dietary Approaches to Stop Hypertension (DASH) trial. Circ. Cardiovasc. Qual. Outcomes 2010, 3, 484-489. [CrossRef] [PubMed]

69. Ard, J.D.; Grambow, S.C.; Liu, D.; Slentz, C.A.; Kraus, W.E.; Svetkey, L.P.; study, P. The effect of the PREMIER interventions on insulin sensitivity. Diabetes Care 2004, 27, 340-347. [CrossRef] [PubMed]

70. Lien, L.F.; Brown, A.J.; Ard, J.D.; Loria, C.; Erlinger, T.P.; Feldstein, A.C.; Lin, P.H.; Champagne, C.M.; King, A.C.; McGuire, H.L.; et al. Effects of PREMIER lifestyle modifications on participants with and without the metabolic syndrome. Hypertension 2007, 50, 609-616. [CrossRef] [PubMed]

71. Al-Solaiman, Y.; Jesri, A.; Zhao, Y.; Morrow, J.D.; Egan, B.M. Low-Sodium DASH reduces oxidative stress and improves vascular function in salt-sensitive humans. J. Hum. Hypertens. 2009, 23, 826-835. [CrossRef] [PubMed]

72. Hodson, L.; Harnden, K.E.; Roberts, R.; Dennis, A.L.; Frayn, K.N. Does the DASH diet lower blood pressure by altering peripheral vascular function? J. Hum. Hypertens. 2010, 24, 312-319. [CrossRef]

73. Ard, J.D.; Coffman, C.J.; Lin, P.H.; Svetkey, L.P. One-year follow-up study of blood pressure and dietary patterns in dietary approaches to stop hypertension (DASH)-sodium participants. Am. J. Hypertens. 2004, 17, 1156-1162. [CrossRef] [PubMed]

74. Elmer, P.J.; Obarzanek, E.; Vollmer, W.M.; Simons-Morton, D.; Stevens, V.J.; Young, D.R.; Lin, P.H.; Champagne, C.; Harsha, D.W.; Svetkey, L.P.; et al. Effects of comprehensive lifestyle modification on diet, weight, physical fitness, and blood pressure control: 18-month results of a randomized trial. Ann. Intern. Med. 2006, 144, 485-495. [CrossRef] [PubMed]

75. Lima, S.T.; da Silva Nalin de Souza, B.; Franca, A.K.; Salgado Filho, N.; Sichieri, R. Dietary approach to hypertension based on low glycaemic index and principles of DASH (Dietary Approaches to Stop Hypertension): A randomised trial in a primary care service. Br. J. Nutr. 2013, 110, 1472-1479. [CrossRef]

76. Rifai, L.; Pisano, C.; Hayden, J.; Sulo, S.; Silver, M.A. Impact of the DASH diet on endothelial function, exercise capacity, and quality of life in patients with heart failure. Bayl. Univ. Med. Cent. Proc. 2015, 28, 151-156. [CrossRef]

77. Asemi, Z.; Samimi, M.; Tabassi, Z.; Esmaillzadeh, A. The effect of DASH diet on pregnancy outcomes in gestational diabetes: A randomized controlled clinical trial. Eur. J. Clin. Nutr. 2014, 68, 490-495. [CrossRef] [PubMed]

78. Razavi Zade, M.; Telkabadi, M.H.; Bahmani, F.; Salehi, B.; Farshbaf, S.; Asemi, Z. The effects of DASH diet on weight loss and metabolic status in adults with non-alcoholic fatty liver disease: A randomized clinical trial. Liver Int. 2016, 36, 563-571. [CrossRef] [PubMed]

79. Jenkins, D.J.; Jones, P.J.; Frohlich, J.; Lamarche, B.; Ireland, C.; Nishi, S.K.; Srichaikul, K.; Galange, P.; Pellini, C.; Faulkner, D.; et al. The effect of a dietary portfolio compared to a DASH-type diet on blood pressure. Nutr. Metab. Cardiovasc. Dis. 2015, 25, 1132-1139. [CrossRef] [PubMed]

80. King, D.E.; Egan, B.M.; Woolson, R.F.; Mainous, A.G., 3rd; Al-Solaiman, Y.; Jesri, A. Effect of a high-fiber diet vs a fiber-supplemented diet on C-reactive protein level. Arch. Intern. Med. 2007, 167, 502-506. [CrossRef] [PubMed]

81. Roussell, M.A.; Hill, A.M.; Gaugler, T.L.; West, S.G.; Heuvel, J.P.; Alaupovic, P.; Gillies, P.J.; Kris-Etherton, P.M. Beef in an Optimal Lean Diet study: Effects on lipids, lipoproteins, and apolipoproteins. Am. J. Clin. Nutr. 2012, 95, 9-16. [CrossRef] [PubMed]

82. Wang, X.; Ouyang, Y.; Liu, J.; Zhu, M.; Zhao, G.; Bao, W.; Hu, F.B. Fruit and vegetable consumption and mortality from all causes, cardiovascular disease, and cancer: Systematic review and dose-response meta-analysis of prospective cohort studies. BMJ 2014, 349, g4490. [CrossRef]

83. Tang, G.; Wang, D.; Long, J.; Yang, F.; Si, L. Meta-analysis of the association between whole grain intake and coronary heart disease risk. Am. J. Cardiol. 2015, 115, 625-629. [CrossRef]

84. Reynolds, A.N. Associations of fats and carbohydrates with cardiovascular disease and mortality-PURE and simple? Lancet 2018, 391, 1676. [CrossRef]

85. Viguiliouk, E.; Blanco Mejia, S.; Kendall, C.W.; Sievenpiper, J.L. Can pulses play a role in improving cardiometabolic health? Evidence from systematic reviews and meta-analyses. Ann. N. Y. Acad. Sci. 2017, 1392, 43-57. [CrossRef]

86. Aune, D.; Keum, N.; Giovannucci, E.; Fadnes, L.T.; Boffetta, P.; Greenwood, D.C.; Tonstad, S.; Vatten, L.J.; Riboli, E.; Norat, T. Nut consumption and risk of cardiovascular disease, total cancer, all-cause and 
cause-specific mortality: A systematic review and dose-response meta-analysis of prospective studies. BMC Med. 2016, 14, 207. [CrossRef] [PubMed]

87. Abete, I.; Romaguera, D.; Vieira, A.R.; Lopez de Munain, A.; Norat, T. Association between total, processed, red and white meat consumption and all-cause, CVD and IHD mortality: A meta-analysis of cohort studies. Br. J. Nutr. 2014, 112, 762-775. [CrossRef] [PubMed]

88. Wang, X.; Lin, X.; Ouyang, Y.Y.; Liu, J.; Zhao, G.; Pan, A.; Hu, F.B. Red and processed meat consumption and mortality: Dose-response meta-analysis of prospective cohort studies. Public Health Nutr. 2016, 19, 893-905. [CrossRef] [PubMed]

89. Threapleton, D.E.; Greenwood, D.C.; Evans, C.E.; Cleghorn, C.L.; Nykjaer, C.; Woodhead, C.; Cade, J.E.; Gale, C.P.; Burley, V.J. Dietary fibre intake and risk of cardiovascular disease: Systematic review and meta-analysis. BMJ 2013, 347, f6879. [CrossRef] [PubMed]

90. Arts, I.C.; Hollman, P.C. Polyphenols and disease risk in epidemiologic studies. Am. J. Clin. Nutr. 2005, 81, 317S-325S. [CrossRef] [PubMed]

91. Perez-Cano, F.J.; Castell, M. Flavonoids, Inflammation and Immune System. Nutrients 2016, 8, 659. [CrossRef] [PubMed]

92. Lim, S.S.; Vos, T.; Flaxman, A.D.; Danaei, G.; Shibuya, K.; Adair-Rohani, H.; Amann, M.; Anderson, H.R.; Andrews, K.G.; Aryee, M.; et al. A comparative risk assessment of burden of disease and injury attributable to 67 risk factors and risk factor clusters in 21 regions, 1990-2010: A systematic analysis for the Global Burden of Disease Study 2010. Lancet 2012, 380, 2224-2260. [CrossRef]

93. Lewington, S.; Clarke, R.; Qizilbash, N.; Peto, R.; Collins, R.; Prospective Studies, Collaboration. Age-specific relevance of usual blood pressure to vascular mortality: A meta-analysis of individual data for one million adults in 61 prospective studies. Lancet 2002, 360, 1903-1913.

94. Cholesterol Treatment Trialists Collaboration; Baigent, C.; Blackwell, L.; Emberson, J.; Holland, L.E.; Reith, C.; Bhala, N.; Peto, R.; Barnes, E.H.; Keech, A.; et al. Efficacy and safety of more intensive lowering of LDL cholesterol: A meta-analysis of data from 170,000 participants in 26 randomised trials. Lancet 2010, 376, 1670-1681.

95. Cholesterol Treatment Trialists Collaboration; Fulcher, J.; O'Connell, R.; Voysey, M.; Emberson, J.; Blackwell, L.; Mihaylova, B.; Simes, J.; Collins, R.; Kirby, A.; et al. Efficacy and safety of LDL-lowering therapy among men and women: Meta-analysis of individual data from 174,000 participants in 27 randomised trials. Lancet 2015, 385, 1397-1405.

96. Cannon, C.P.; Blazing, M.A.; Giugliano, R.P.; McCagg, A.; White, J.A.; Theroux, P.; Darius, H.; Lewis, B.S.; Ophuis, T.O.; Jukema, J.W.; et al. Ezetimibe Added to Statin Therapy after Acute Coronary Syndromes. N. Engl. J. Med. 2015, 372, 2387-2397. [CrossRef] [PubMed]

97. Johnston, B.C.; Kanters, S.; Bandayrel, K.; Wu, P.; Naji, F.; Siemieniuk, R.A.; Ball, G.D.; Busse, J.W.; Thorlund, K.; Guyatt, G.; et al. Comparison of weight loss among named diet programs in overweight and obese adults: A meta-analysis. JAMA 2014, 312, 923-933. [CrossRef] [PubMed]

98. Haslam, D.W.; James, W.P. Obesity. Lancet 2005, 366, 1197-1209. [CrossRef]

99. Sotos-Prieto, M.; Bhupathiraju, S.N.; Mattei, J.; Fung, T.T.; Li, Y.; Pan, A.; Willett, W.C.; Rimm, E.B.; Hu, F.B. Association of Changes in Diet Quality with Total and Cause-Specific Mortality. N. Engl. J. Med. 2017, 377, 143-153. [CrossRef] [PubMed]

100. Li, M.; Fan, Y.; Zhang, X.; Hou, W.; Tang, Z. Fruit and vegetable intake and risk of type 2 diabetes mellitus: Meta-analysis of prospective cohort studies. BMJ Open 2014, 4, e05497. [CrossRef] [PubMed]

101. Gijsbers, L.; Ding, E.L.; Malik, V.S.; de Goede, J.; Geleijnse, J.M.; Soedamah-Muthu, S.S. Consumption of dairy foods and diabetes incidence: A dose-response meta-analysis of observational studies. Am. J. Clin. Nutr. 2016, 103, 1111-1124. [CrossRef] [PubMed]

102. Wei, G.S.; Coady, S.A.; Goff, D.C., Jr.; Brancati, F.L.; Levy, D.; Selvin, E.; Vasan, R.S.; Fox, C.S. Blood pressure and the risk of developing diabetes in african americans and whites: ARIC, CARDIA, and the framingham heart study. Diabetes Care 2011, 34, 873-879. [CrossRef]

103. Emdin, C.A.; Anderson, S.G.; Woodward, M.; Rahimi, K. Usual Blood Pressure and Risk of New-Onset Diabetes: Evidence From 4.1 Million Adults and a Meta-Analysis of Prospective Studies. J. Am. Coll. Cardiol. 2015, 66, 1552-1562. [CrossRef]

104. Marott, S.C.; Nordestgaard, B.G.; Tybjaerg-Hansen, A.; Benn, M. Components of the Metabolic Syndrome and Risk of Type 2 Diabetes. J. Clin. Endocrinol. Metab. 2016, 101, 3212-3221. [CrossRef] 
105. Post, R.E.; Mainous, A.G., 3rd; King, D.E.; Simpson, K.N. Dietary fiber for the treatment of type 2 diabetes mellitus: A meta-analysis. J. Am. Board Fam. Med. 2012, 25, 16-23. [CrossRef]

106. Evans, C.E.; Greenwood, D.C.; Threapleton, D.E.; Cleghorn, C.L.; Nykjaer, C.; Woodhead, C.E.; Gale, C.P.; Burley, V.J. Effects of dietary fibre type on blood pressure: A systematic review and meta-analysis of randomized controlled trials of healthy individuals. J. Hypertens. 2015, 33, 897-911. [CrossRef] [PubMed]

107. Hou, Q.; Li, Y.; Li, L.; Cheng, G.; Sun, X.; Li, S.; Tian, H. The Metabolic Effects of Oats Intake in Patients with Type 2 Diabetes: A Systematic Review and Meta-Analysis. Nutrients 2015, 7, 10369-10387. [CrossRef] [PubMed]

108. Sievenpiper, J.L.; Kendall, C.W.; Esfahani, A.; Wong, J.M.; Carleton, A.J.; Jiang, H.Y.; Bazinet, R.P.; Vidgen, E.; Jenkins, D.J. Effect of non-oil-seed pulses on glycaemic control: A systematic review and meta-analysis of randomised controlled experimental trials in people with and without diabetes. Diabetologia 2009, 52, 1479-1495. [CrossRef] [PubMed]

109. Choo, V.L.; Viguiliouk, E.; Blanco Mejia, S.; Cozma, A.I.; Khan, T.A.; Ha, V.; Wolever, T.M.S.; Leiter, L.A.; Vuksan, V.; Kendall, C.W.C.; et al. Food sources of fructose-containing sugars and glycaemic control: Systematic review and meta-analysis of controlled intervention studies. BMJ 2018, 363, k4644. [CrossRef] [PubMed]

110. InterAct Consortium. Dietary fibre and incidence of type 2 diabetes in eight European countries: The EPIC-InterAct Study and a meta-analysis of prospective studies. Diabetologia 2015, 58, 1394-1408. [CrossRef] [PubMed]

111. Aune, D.; Norat, T.; Romundstad, P.; Vatten, L.J. Whole grain and refined grain consumption and the risk of type 2 diabetes: A systematic review and dose-response meta-analysis of cohort studies. Eur. J. Epidemiol. 2013, 28, 845-858. [CrossRef] [PubMed]

112. Kotchen, T.A.; Kotchen, J.M. Dietary sodium and blood pressure: Interactions with other nutrients. Am. J. Clin. Nutr. 1997, 65, 708S-711S. [CrossRef]

113. Whelton, P.K.; He, J.; Cutler, J.A.; Brancati, F.L.; Appel, L.J.; Follmann, D.; Klag, M.J. Effects of oral potassium on blood pressure. Meta-analysis of randomized controlled clinical trials. JAMA 1997, 277, 1624-1632. [CrossRef]

114. Petrov, V.; Lijnen, P. Modification of intracellular calcium and plasma renin by dietary calcium in men. Am. J. Hypertens. 1999, 12, 1217-1224. [CrossRef]

115. Kanbay, M.; Bayram, Y.; Solak, Y.; Sanders, P.W. Dietary potassium: A key mediator of the cardiovascular response to dietary sodium chloride. J. Am. Soc. Hypertens. 2013, 7, 395-400. [CrossRef]

116. Haddy, F.J.; Vanhoutte, P.M.; Feletou, M. Role of potassium in regulating blood flow and blood pressure. Am. J. Physiol. Regul. Integr. Comp. Physiol. 2006, 290, R546-R552. [CrossRef] [PubMed]

117. Zacchia, M.; Abategiovanni, M.L.; Stratigis, S.; Capasso, G. Potassium: From Physiology to Clinical Implications. Kidney Dis. (Basel) 2016, 2, 72-79. [CrossRef] [PubMed]

118. Siervo, M.; Lara, J.; Ogbonmwan, I.; Mathers, J.C. Inorganic nitrate and beetroot juice supplementation reduces blood pressure in adults: A systematic review and meta-analysis. J. Nutr. 2013, 143, 818-826. [CrossRef] [PubMed]

119. Jayalath, V.H.; de Souza, R.J.; Sievenpiper, J.L.; Ha, V.; Chiavaroli, L.; Mirrahimi, A.; Di Buono, M.; Bernstein, A.M.; Leiter, L.A.; Kris-Etherton, P.M.; et al. Effect of dietary pulses on blood pressure: A systematic review and meta-analysis of controlled feeding trials. Am. J. Hypertens. 2014, 27, 56-64. [PubMed]

120. Huang, H.; Chen, G.; Liao, D.; Zhu, Y.; Xue, X. Effects of Berries Consumption on Cardiovascular Risk Factors: A Meta-analysis with Trial Sequential Analysis of Randomized Controlled Trials. Sci. Rep. 2016, 6, 23625. [CrossRef] [PubMed]

121. Khan, K.; Jovanovski, E.; Ho, H.V.T.; Marques, A.C.R.; Zurbau, A.; Mejia, S.B.; Sievenpiper, J.L.; Vuksan, V. The effect of viscous soluble fiber on blood pressure: A systematic review and meta-analysis of randomized controlled trials. Nutr. Metab. Cardiovasc. Dis. 2018, 28, 3-13. [CrossRef] [PubMed]

122. Ho, H.V.; Sievenpiper, J.L.; Zurbau, A.; Blanco Mejia, S.; Jovanovski, E.; Au-Yeung, F.; Jenkins, A.L.; Vuksan, V. The effect of oat beta-glucan on LDL-cholesterol, non-HDL-cholesterol and apoB for CVD risk reduction: A systematic review and meta-analysis of randomised-controlled trials. Br. J. Nutr. 2016, 116, 1369-1382. [CrossRef] [PubMed] 
123. Hollaender, P.L.; Ross, A.B.; Kristensen, M. Whole-grain and blood lipid changes in apparently healthy adults: A systematic review and meta-analysis of randomized controlled studies. Am. J. Clin. Nutr. 2015, 102, 556-572. [CrossRef]

124. Ha, V.; Sievenpiper, J.L.; de Souza, R.J.; Jayalath, V.H.; Mirrahimi, A.; Agarwal, A.; Chiavaroli, L.; Mejia, S.B.; Sacks, F.M.; Di Buono, M.; et al. Effect of dietary pulse intake on established therapeutic lipid targets for cardiovascular risk reduction: A systematic review and meta-analysis of randomized controlled trials. CMAJ 2014, 186, E252-E262. [CrossRef]

125. Hooper, L.; Martin, N.; Abdelhamid, A.; Davey Smith, G. Reduction in saturated fat intake for cardiovascular disease. Cochrane Database Syst. Rev. 2015. [CrossRef]

126. Chiavaroli, L.; Nishi, S.K.; Khan, T.A.; Braunstein, C.R.; Glenn, A.J.; Mejia, S.B.; Rahelic, D.; Kahleova, H.; Salas-Salvado, J.; Jenkins, D.J.A.; et al. Portfolio Dietary Pattern and Cardiovascular Disease: A Systematic Review and Meta-analysis of Controlled Trials. Prog. Cardiovasc. Dis. 2018, 61, 43-53. [CrossRef] [PubMed]

127. Mytton, O.T.; Nnoaham, K.; Eyles, H.; Scarborough, P.; Ni Mhurchu, C. Systematic review and meta-analysis of the effect of increased vegetable and fruit consumption on body weight and energy intake. BMC Public Health 2014, 14, 886. [CrossRef] [PubMed]

128. Howarth, N.C.; Saltzman, E.; Roberts, S.B. Dietary fiber and weight regulation. Nutr. Rev. 2001, 59, $129-139$. [CrossRef] [PubMed]

129. Kim, S.J.; de Souza, R.J.; Choo, V.L.; Ha, V.; Cozma, A.I.; Chiavaroli, L.; Mirrahimi, A.; Blanco Mejia, S.; Di Buono, M.; Bernstein, A.M.; et al. Effects of dietary pulse consumption on body weight: A systematic review and meta-analysis of randomized controlled trials. Am. J. Clin. Nutr. 2016, 103, 1213-1223. [CrossRef] [PubMed]

130. Li, S.S.; Kendall, C.W.; de Souza, R.J.; Jayalath, V.H.; Cozma, A.I.; Ha, V.; Mirrahimi, A.; Chiavaroli, L.; Augustin, L.S.; Blanco Mejia, S.; et al. Dietary pulses, satiety and food intake: A systematic review and meta-analysis of acute feeding trials. Obesity (Silver Spring) 2014, 22, 1773-1780. [CrossRef] [PubMed]

131. Oh, S.W.; Han, K.H.; Han, S.Y.; Koo, H.S.; Kim, S.; Chin, H.J. Association of Sodium Excretion With Metabolic Syndrome, Insulin Resistance, and Body Fat. Medicine (Baltimore) 2015, 94, e1650. [CrossRef] [PubMed]

132. Jiao, J.; Xu, J.Y.; Zhang, W.; Han, S.; Qin, L.Q. Effect of dietary fiber on circulating C-reactive protein in overweight and obese adults: A meta-analysis of randomized controlled trials. Int. J. Food Sci. Nutr. 2015, 66, 114-119. [CrossRef]

133. Estruch, R.; Martinez-Gonzalez, M.A.; Corella, D.; Basora-Gallisa, J.; Ruiz-Gutierrez, V.; Covas, M.I.; Fiol, M.; Gomez-Gracia, E.; Lopez-Sabater, M.C.; Escoda, R.; et al. Effects of dietary fibre intake on risk factors for cardiovascular disease in subjects at high risk. J. Epidemiol. Community Health 2009, 63, 582-588. [CrossRef]

134. Kanauchi, O.; Mitsuyama, K.; Araki, Y.; Andoh, A. Modification of intestinal flora in the treatment of inflammatory bowel disease. Curr. Pharm Des. 2003, 9, 333-346. [CrossRef]

135. Scheppach, W.; Wiggins, H.S.; Halliday, D.; Self, R.; Howard, J.; Branch, W.J.; Schrezenmeir, J.; Cummings, J.H. Effect of gut-derived acetate on glucose turnover in man. Clin. Sci. (Lond.) 1988, 75, 363-370. [CrossRef]

136. Lee, Y.; Kang, D.; Lee, S.A. Effect of dietary patterns on serum C-reactive protein level. Nutr. Metab. Cardiovasc. Dis. 2014, 24, 1004-1011. [CrossRef] [PubMed]

137. Watzl, B.; Kulling, S.E.; Moseneder, J.; Barth, S.W.; Bub, A. A 4-wk intervention with high intake of carotenoid-rich vegetables and fruit reduces plasma C-reactive protein in healthy, nonsmoking men. Am. J. Clin. Nutr. 2005, 82, 1052-1058. [CrossRef] [PubMed]

138. Dibaba, D.T.; Xun, P.; He, K. Dietary magnesium intake is inversely associated with serum C-reactive protein levels: Meta-analysis and systematic review. Eur. J. Clin. Nutr. 2014, 68, 971. [CrossRef] [PubMed]

139. Almoznino-Sarafian, D.; Berman, S.; Mor, A.; Shteinshnaider, M.; Gorelik, O.; Tzur, I.; Alon, I.; Modai, D.; Cohen, N. Magnesium and C-reactive protein in heart failure: An anti-inflammatory effect of magnesium administration? Eur. J. Nutr. 2007, 46, 230-237. [CrossRef] [PubMed]

140. Chen, X.; Touyz, R.M.; Park, J.B.; Schiffrin, E.L. Antioxidant effects of vitamins C and E are associated with altered activation of vascular NADPH oxidase and superoxide dismutase in stroke-prone SHR. Hypertension 2001, 38, 606-611. [CrossRef] [PubMed]

141. Yang, Y.; Gao, M.; Nie, W.; Yuan, J.; Zhang, B.; Wang, Z.; Wu, Z. Dietary magnesium sulfate supplementation protects heat stress-induced oxidative damage by restoring the activities of anti-oxidative enzymes in broilers. Biol. Trace Elem. Res. 2012, 146, 53-58. [CrossRef] [PubMed] 
142. Blanco Mejia, S.; Kendall, C.W.; Viguiliouk, E.; Augustin, L.S.; Ha, V.; Cozma, A.I.; Mirrahimi, A.; Maroleanu, A.; Chiavaroli, L.; Leiter, L.A.; et al. Effect of tree nuts on metabolic syndrome criteria: A systematic review and meta-analysis of randomised controlled trials. BMJ Open 2014, 4, e004660. [CrossRef]

143. Ho, H.V.; Sievenpiper, J.L.; Zurbau, A.; Blanco Mejia, S.; Jovanovski, E.; Au-Yeung, F.; Jenkins, A.L.; Vuksan, V. A systematic review and meta-analysis of randomized controlled trials of the effect of barley beta-glucan on LDL-C, non-HDL-C and apoB for cardiovascular disease risk reduction(i-iv). Eur. J. Clin. Nutr. 2016, 70, 1340. [CrossRef]

144. Health Promotion and Disease Prevention: Fruit and Vegetables. European Commission. Available online: https: / / ec.europa.eu/jrc/en/health-knowledge-gateway/promotion-prevention/nutrition/fruitvegetables\#_jrc2018 (accessed on 28 November 2018).

145. Health Promotion and Disease Prevention: Dietary Fats. European Commission. Available online: https:// ec.europa.eu/jrc/en/health-knowledge-gateway/promotion-prevention/nutrition/fats\#_Toctb5b (accessed on 28 November 2018).

146. Hjartaker, A.; Lagiou, A.; Slimani, N.; Lund, E.; Chirlaque, M.D.; Vasilopoulou, E.; Zavitsanos, X.; Berrino, F.; Sacerdote, C.; Ocke, M.C.; et al. Consumption of dairy products in the European Prospective Investigation into Cancer and Nutrition (EPIC) cohort: Data from 35,955 24-hour dietary recalls in 10 European countries. Public Health Nutr. 2002, 5, 1259-1271. [CrossRef]

147. Lee-Kwan, S.H.; Moore, L.V.; Blanck, H.M.; Harris, D.M.; Galuska, D. Disparities in State-Specific Adult Fruit and Vegetable Consumption-United States, 2015. MMWR Morb. Mortal Wkly. Rep. 2017, 66, 1241-1247. [CrossRef]

148. U. S. Department of Agricultural Service. Food Patterns Equivalents Intakes from Food: Mean Amounts Consumed per Individual, by Gender and Age, What We Eat In America, NHANES 2009-2010. 2013. Available online: www.ars.usda.gov/ba/bhnrc/fsrg (accessed on 27 November 2018).

149. Nielsen, S.J.; Kit, B.K.; Ogden, C.L. Nut Consumption Among U.S. Adults, 2009-2010. NCHS Data Brief. 2014, 176, 1-8.

(C) 2019 by the authors. Licensee MDPI, Basel, Switzerland. This article is an open access article distributed under the terms and conditions of the Creative Commons Attribution (CC BY) license (http://creativecommons.org/licenses/by/4.0/). 